\title{
An overview of the recent approaches to terroir functional modelling, footprinting and zoning
}

\author{
E. Vaudour ${ }^{1,2}$, E. Costantini ${ }^{3}$, G. V. Jones ${ }^{4}$, and S. Mocali $^{3}$ \\ ${ }^{1}$ AgroParisTech, UMR1402 INRA/AgroParisTech ECOSYS, Pôle Sol, avenue Lucien Brétignières, \\ 78850 Thiverval-Grignon, France \\ ${ }^{2}$ INRA, UMR1402 INRA/AgroParisTech ECOSYS, Pôle Sol, avenue Lucien Brétignières, \\ 78850 Thiverval-Grignon, France \\ ${ }^{3}$ Consiglio per la ricerca in agricoltura e l'analisi dell'economia agraria (CRA), Agrobiology and Pedology \\ Research Centre (CRA-ABP) D'Azeglio 30, Firenze 50121, Italy \\ ${ }^{4}$ Department of Environmental Studies 101A Taylor Hall, Ashland, OR 97520, USA
}

Correspondence to: E. Vaudour (emmanuelle.vaudour@agroparistech.fr)

Received: 29 October 2014 - Published in SOIL Discuss.: 20 November 2014

Revised: - - Accepted: 27 February 2015 - Published: 18 March 2015

\begin{abstract}
Notions of terroir and their conceptualization through agro-environmental sciences have become popular in many parts of world. Originally developed for wine, terroir now encompasses many other crops including fruits, vegetables, cheese, olive oil, coffee, cacao and other crops, linking the uniqueness and quality of both beverages and foods to the environment where they are produced, giving the consumer a sense of place. Climate, geology, geomorphology and soil are the main environmental factors which make up the terroir effect on different scales. Often considered immutable culturally, the natural components of terroir are actually a set of processes, which together create a delicate equilibrium and regulation of its effect on products in both space and time. Due to both a greater need to better understand regional-to-site variations in crop production and the growth in spatial analytic technologies, the study of terroir has shifted from a largely descriptive regional science to a more applied, technical research field. Furthermore, the explosion of spatial data availability and sensing technologies has made the within-field scale of study more valuable to the individual grower. The result has been greater adoption of these technologies but also issues associated with both the spatial and temporal scales required for practical applications, as well as the relevant approaches for data synthesis. Moreover, as soil microbial communities are known to be of vital importance for terrestrial processes by driving the major soil geochemical cycles and supporting healthy plant growth, an intensive investigation of the microbial organization and their function is also required. Our objective is to present an overview of existing data and modelling approaches for terroir functional modelling, footprinting and zoning on local and regional scales. This review will focus on two main areas of recent terroir research: (1) using new tools to unravel the biogeochemical cycles of both macro- and micronutrients, the biological and chemical signatures of terroirs (i.e. the metagenomic approach and regional fingerprinting); (2) terroir zoning on different scales: mapping terroirs and using remoteand proxy-sensing technologies to monitor soil quality and manage the crop system for better food quality. Both implementations of terroir chemical and biological footprinting and geospatial technologies are promising for the management of terroir units, particularly the remote and proxy data in conjunction with spatial statistics. Indeed, the managed zones will be updatable and the effects of viticultural and/or soil management practices might be easier to control. The prospect of facilitated terroir spatial monitoring makes it possible to address another great challenge in the years to come: the issue of terroir sustainability and the construction of efficient soil/viticultural management strategies that can be assessed and applied across numerous scales.
\end{abstract}




\section{Introduction}

A search using the keyword "terroir" in the Scopus database finds 385 papers published from 1980 to 2014 (September) including a steady rise from 2005 to 2014 . This trend provides evidence of the ever-growing interest of the scientific community in understanding the characteristics and relationships between the many factors of terroir. "Terroir" is a French word, meaning delimited areas with homogeneous environmental features that are likely to confer typical wine qualities identified through collective memory and conveyed from generation to generation within a territory marked by social context and cultural technical choices (Vaudour, 2002, 2003). The tradition of terroir wines has strong cultural connections, referring to tradition of drinking well, of farming and of producing typical wines that are rooted in a region or made from specific places with organoleptic features easily distinguishable from other wines from other regions. In France these are sometimes named "crus", "clos" and, in the case of Burgundy, "climats". In making a typical wine originating from a given terroir unit, fields or subfields are assigned to this unit and grapes of one or several specific varieties are combined in containers within a winery: as such winegrowing terroirs need to be managed across the geographical space. Both Greek and Latin agronomists developed and used recommendations for the spatial management of terroirs, as exemplified by the Amos farming leases dating back the High Hellenistic period. These leases discriminated between vineyards planted on the "plains" and vineyards planted in "rocky terrains", with differing prescriptions for vineyard planting densities (Vaudour and Boulay, 2013). Inherited from medieval times and monasteries, highresolution grapevine selection from small-sized fields of some hundreds of square metres has long been practiced for the making of famous crus in small volumes (barrels of $200 \mathrm{hL}$ ) (Dion, 1990; Unwin, 1991). In that sense, the shaping of terroirs results from a long heuristic process (likely hundreds of years) through history, marked by discontinuities due to wars, the spread of plagues and wine market opportunities. For centuries, such heuristic processes have mostly been carried out on less fertile soils (fertile soils being reserved for annual crop cultivation) and without resorting to irrigation, thus accentuating multi-year variability due to vintage weather ("millésime" effect). As an entity distributed over space and time, terroir has cultural aspects that have heritage, landscape and reputation value-added components (Tomasi et al., 2013) that come from historical, empirically derived technical adjustments, the transmission of taste typicity over generations and strong gastronomical traditions. On the other hand, the agro-environmental aspects of terroir are likely to be conceptualized, in order to characterize, delineate and monitor zones with homogeneous or outstanding grape and/or wine, soil, geomorphological, geo- logical, landscape and climate characteristics at a given spatial level and over a given duration. This process may be in the nascent stages of understanding vineyard spatial management in young winegrowing regions or refined in those winegrowing regions with long-lived wine traditions.

On the international scale, a definition focused on the agro-environmental facets of terroir was adopted in 2010 by the International Vine and Wine Organization (resolution OIV/VITI 333/2010). Originally developed for wine, approaches for defining terroirs are now being carried to other specialty crops such as coffee (e.g. De Assis Silva et al., 2014), tea (e.g. Besky, 2014), tequila (Bowen and Zapata, 2009), honey, maple syrup, cacao, olive oil, fruits, vegetables and cheese (Trubek, 2008; Jacobsen, 2010), ultimately linking the uniqueness and quality of both beverages and foods to the environment where they are produced. The trend for providing the consumer a sense of a place has historically developed alongside the legal protection of these products, through either "protected designations of origin" (PDOs) or "protected geographical indications" (PGIs). However, although they both rely on the assumption of a deterministic relationship between food quality and agro-environmental features, legal definitions of PDOs and PGIs are not always spatially representative of the terroirs they come from. In the European Union for instance, PDOs refer to the names of regions, given areas or even countries assigned to agricultural crops or value-added products which are produced, processed or prepared in a region according to traditional methods. In France, Italy and Spain, official PDOs that provide terroir wines with legal protection from falsified wines from other areas date back to 1935 (Vaudour, 2003). However, there have been many historical precursors of PDOs, such as, Chianti in the 17th century (Tomasi et al., 2013) or Jerez (Cabral Chamorro, 1987) and Champagne (Marre, 2004) in the 19th century. Under a PDO, winegrowers, winemakers and experts jointly define those zones that are permitted to produce wines named after their most renowned places, under common producing rules considered as traditional. These zones are generally based on pre-existing boundaries of administrative districts or easily demarcating patterns derived from hydrological networks, roads or railways. In contrast, PGIs refer to the names of areas, with some link to product quality and with at least one of the stages of production, processing or preparation occurring in the area in question. Despite differing definitions, terroir is sometimes confused with PDO or may even be confused with PGI (Barham, 2003), when one or, more likely, several terroir units may constitute the delimitated areas within the PDO, be included in them, or even intersect them.

In whatever winegrowing region in the world, when valuing inherited management zones or attempting to construct them, the so-called "natural" components of terroir actually result from a set of processes, which together with viticul- 
tural practices create a delicate equilibrium and regulate its effect on products in both space and time (Van Leeuwen et al., 2004; Deloire et al., 2005; Van Leeuwen and Seguin, 2006; Costantini and Bucelli, 2014). In its most basic sense, the so-called "concept of terroir" relates the sensory attributes of wine to the environmental conditions in which the grapes are grown (Van Leeuwen and Seguin, 2006; White et al., 2007; Tempesta et al., 2010).

Given the economic importance of the wine industry worldwide, there is clearly a need to better understand the spatial and temporal variability of grape composition and which spatial and cultural scales and resolutions are best suited to manage the production of terroir wines that reveal the typical qualities of terroir units across a given territory, together with minimizing the environmental impacts of this production. Underlying notions of such questioning stem from two main research areas: first, the concepts and knowledge of agro-ecosystems, raised and revisited for present-day agriculture, which faces an increasing number of challenges, including ensuring various ecosystem services by means of implementing agro-ecological practices (Doré et al., 2011; Wezel et al., 2014); second, concepts of and approaches to digital soil assessment based on pedometrics and/or proxy remote-sensing techniques (Carré et al., 2007; Minasny et al., 2013; Werban et al., 2013; Hartemink and Minasny, 2014). These challenges go hand in hand with the need for an interdisciplinary approach of soil (Brevik et al., 2015). There is a greater need to understand regional-to-site and site-toregional variations in crop production, and the growth in spatial analytic technologies is likely to facilitate downscaling and upscaling approaches to address these needs. Together with the emergence of precision viticulture, the explosion of spatial data availability and geospatial technologies in the past 15 years has made the within-field and farm scale of research more valuable to the individual grower, resulting in greater adoption and application (Tomasi et al., 2013). Furthermore, the study of terroir has shifted from a largely descriptive regional science back in the 1990s to a more applied, technical research field at the beginning of the 21st century. Confusion between PDOs and terroir, and the strict observance of no irrigation, according to historical heuristic processes of terroir, results in misleading questions such as the possible compatibility of terroir and precision viticulture (Bramley and Hamilton, 2007). However, the long process of terroir identification over time questions those practices that enhance or diminish terroir sustainability, particularly in recent times with the advent of modern viticulture. For example, viticultural soils appear to be exposed to degradation processes, perhaps more than ever, because of unsuitable practices in land management (Blavet et al., 2009; Follain et al., 2012; Costantini and Lorenzetti, 2013). In addition, soil contamination by copper resulting from the cumulated use of Bordeaux mixture and other copper fungicides is increasingly an issue (Pieztrak and McPhail, 2004; Fernández-Calviño et al., 2013; Chopin et al., 2008; Mirlean et al., 2007, 2009; El Hadri et al., 2012; El Azzi et al., 2013) and appears to result in modifying the spatial distribution and composition of soil microbial communities (Jacobson et al., 2007; Mackie et al., 2013). Because of water scarcity, irrigation may be practiced with saline water or saline effluent, with possible deleterious effects on plant growth (Walker et al., 2002; Paranychianakis and Angelakis, 2008; Stevens et al., 2010, 2011) and on soil salinity, structure and quality (Crescimanno et al., 2007; Urdanoz and Aragüés, 2009). Thus, an intensive investigation of the microbial and fungal organization and their function is required, as soil microbial and fungal communities are known to be of vital importance for terrestrial processes by driving the major soil geochemical cycles and supporting healthy plant growth (Nannipieri et al., 2003; Bokulich et al., 2014).

Our objective is therefore to present an overview of existing data and analytical and modelling approaches for the footprinting and zoning of terroirs on local and regional scales. This review will focus on two main areas of recent terroir research: (1) new tools for assessing terroir footprints, comprising metabolomics, the metagenomic approach and microbial and chemical fingerprinting; (2) terroir zoning on different scales, using remote- and proxy-sensing technologies to spatially manage the crop system for higher quality and to spatially monitor the soil quality.

\section{Emerging tools for assessing terroir footprints}

\subsection{Chemical fingerprint and metabolomics}

Wines from distinct countries or regions can be discriminated through their chemical composition and/or sensorial profiles. A recent study quantifying a large number of elements (33) in wine and soil samples analysed by quadrupole inductively coupled plasma mass spectrometry (Q-ICPMS) in addition to ${ }^{87} \mathrm{Sr} /{ }^{86} \mathrm{Sr}$ isotopic analysis allowed for differentiation among the wine-producing regions of Argentina (Di PaolaNaranjo et al., 2011). In this case the ${ }^{87} \mathrm{Sr} /{ }^{86} \mathrm{Sr}$ ratio was amongst the best discriminators, and its value ranges were similar between soils and wines. This corroborates the results obtained by Marchionni et al. (2013) across six distinct wine appellations in Italy, but in their study they focused on parent material; the ratio matched those observed for homogeneous soil parental material such as volcanic rocks. Studying the whole parent-material-soil-plant-wine chain at a single rainfed vineyard located in the volcanic area of Campi Flegrei (southern Italy) and considering both a set of putative rare-earth elements geotracers and the $\mathrm{Sr}$ isotope ratio, Mercurio et al. (2014) found that only this isotopic ratio was "consistently and inherently transferred and maintained from geologic parent material to wine, through soil horizons, branches, leaves, and grapes". However, considering several vintages, Marchionni et al. (2013) observed that wines showing $\mathrm{Sr}$ isotopic ratios matching those of the underlying substrates mostly originated from vineyards grown on 
volcanic rocks, unlike wines from vineyards on sedimentary or granitic rocks. As isotopic ratios of geological substrates belonging to different geological districts may partially overlap, Mercurio et al. (2014) recommend assessing the isotopic ratios together with a pertinent soil classification for a reliable assurance of wine provenance. Geographical fingerprinting of wines may also be possible with areas as close to one another as $4 \mathrm{~km}$. Research by Tarr et al. (2013) found that more than a thousand components were identified through the high-performance liquid chromatography of juices from two varieties (Syrah and Grenache) originating from two distinct terroirs roughly $4 \mathrm{~km}$ from each other. Hierarchical clustering of data peaks suggested that terroir played a large part in the final composition of the grape berry metabolome (Tarr et al., 2013).

Metabolomics seek to identify the chemical fingerprint of a particular cell, organ, organism or tissue type that results from and is thus indicative of the chemical processes that occur within the specimen of analysis (Tarr et al., 2013). Using metabolite and gene transcript profiling, Castellarin et al. (2007) highlighted that the biosynthesis pathway of flavonols related to water deficit and nitrogen nutrition. The first reaction involves the deamination of phenylalanine by the enzyme phenylalanine ammonia lyase (PAL) into cinnamic acid, thus diverting phenylalanine from the pathway that relates carbohydrates to the synthesis of proteins. Metabolomic studies have also been conducted through Proton nuclear magnetic resonance $\left({ }^{1} \mathrm{H}\right.$ NMR) spectroscopy (Pereira et al., 2006; Son et al., 2009), which revealed that grapes grown in regions with high sun exposure and low rainfall showed higher levels of sugar, proline, $\mathrm{Na}$ and $\mathrm{Ca}$ together with lower levels of malate, citrate, alanine, threonine and trigonelline than those grown in regions with relatively low sun exposure and high rainfall (Son et al., 2009). The sensitivity of this method has allowed it to be successfully applied to classify wines according to their phenolic profile and allowed distinguishing between wines from different wineries of the same wine-producing zone and between different vintages for wines of the same variety in Greece (Anastasiadi et al., 2009) and Spain (López-Rituerto et al., 2012).

\subsection{Biological fingerprinting through molecular and "omics" approaches}

Despite the fact that the interaction between microbial communities and the vine may be one of the key factors that influence the plant traits, the role of microbes for terroir and vine traits has been largely ignored (Gilbert et al., 2014). However, the recent development of the so-called "omics" techniques (mainly metagenomics, metabolomics, transcriptomics, proteomics, phenomics) has made it possible to explore the soil functionality, microbial diversity (microbiome) and vine-associated microorganisms in greater detail. In fact, the application of omics techniques to soil may enable the determination of rare microbial species and discover new com- pounds or functions (antibiotic, enzymes, etc.) from the expression of genes of unknown microbial species (Myrold and Nannipieri, 2014). Thus, the application of omics techniques in soil microbiology, together with standard techniques for soil science, is promising for understanding the functioning of soil and its effect on terroir. To date few studies have been carried out on this issue.

The interface between roots and soil (rhizosphere) is often considered the key point of interaction between a plant and its environment. Microbes colonizing at the root may migrate through the plant to colonize aerial tissues, either internally (endophytes) or externally (epiphytes) (Compant et al., 2011; Bulgarelli et al., 2013). In addition to soil, the exploitation of the commensal microbial flora that coexists with the vine may be one of the key factors that influence the plant traits.

Most studies dealing with biological fingerprinting are related to the microbial communities present on the surface of the grape berry, which are known to be very large and which change according to the stage of grape development (Barata et al., 2012; Pinto et al., 2014). In fact, the microbiological life of wine starts before the reception and fermentation of the grapes at the winery. In particular the yeast population and bacterial and fungal consortia inhabiting grape surfaces could reflect a wine region, as reported in some recent studies (Renouf et al., 2005; Setati et al., 2012; Bokulich et al., 2013). However, determinants of regional wine characteristics have not been identified. Renouf et al. (2007) identified 52 yeast species and 40 bacteria. The majority of the bacterial groups were present in the study, in particular the proteobacteria, which are not commonly described in oenology, while the most common oenological yeast (Saccharomyces cerevisiae, Brettanomyces bruxellensis) and bacteria (Oenococcus oeni, Pediococcus parvulus, Gluconobacter oxydans) were detected on grape skins from the first stages of development.

Bokulich et al. (2013) surveyed 273 grape musts from two vintages of Chardonnay, Zinfandel and Cabernet Sauvignon, demonstrating that the grape surface microbial communities present were significantly different between regions (Fig. 1). The authors also showed that the degree of significant differentiation between regions is increased dramatically when they look at the biogeography within a grape variety of a given vintage, and they alluded to "the existence of non-random 'microbial terroir' as a determining factor in regional variation among wine grapes". This finding suggests that other factors also play a significant role, including host genotype, phenotype (grape variety), local and interannual climate variation (vintage), and soil quality. However, the specific role of soil microbes was not determined.

In a recent work Martins et al. (2013) observed the interaction between telluric bacterial communities and the epiphytic bacteria present on the different grapevine parts. Yet, the ecological interactions and the role of such organisms are still not clear. Vega-Avila et al. (2015) reported how soil management (organic vs. conventional) could affect the structure and 


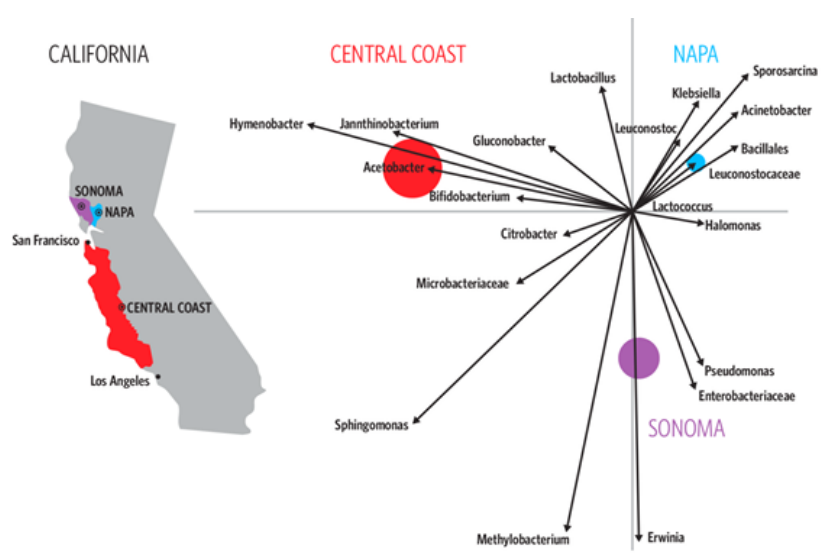

Figure 1. Differences in grape surface microbial communities present between wine regions of California. From https:// cosmosmagazine.com/earth-sciences/winemaking-art-or-science.

the diversity of bacterial communities in the rhizosphere of vines of the variety Syrah, in Argentina. Indeed, most of the available literature reports studies concerning the bacterial structure and plant-associated microbiomes (i.e. Dell' Amico et al., 2008; Gilbert et al., 2014), but the functional diversity of such microbiomes is still largely ignored. The combination of different high-throughput culture-independent methods, such as microarrays, metagenomics and microbiome, might elucidate such aspects. For example, considering soils from two sites close to each other in central Tuscany cultivated with the same variety (Sangiovese) but with contrasting wine quality and water stress, Mocali et al. (2013) used functional GeoChip microarrays and high-throughput DNA sequencing of rRNA genes to explore both microbial composition and functions. Preliminary results revealed different amounts of Actinobacteria and Proteobacteria among the two sites and an overrepresentation of sulfur-oxidation genes in samples where both the increased level of sulfates and the abundance of Firmicutes such as Sulfobacillus thermosulfidooxidans occurred. A further step might be to sequence the entire genomic DNA present in a vineyard soil sample and referred to as the "metagenome", which could provide a cultivation-independent assessment of the largely unexplored genetic reservoir of soil microbial communities and their functions (Daniel, 2005; Mocali and Benedetti, 2010). The importance of this approach has led to the establishment of "Terragenome", an international consortium for the exploitation of the soil metagenome (Vogel et al., 2009). While these studies represent an initial examination of these relationships, they represent an essential step which may potentially help to revolutionize how sites for agriculture are chosen or, indeed, how they could be manipulated by probiotics designed to select suitable bacterial species, which could improve soil quality and, hence, crop productivity. Further research is needed to study the degree to which the use of probiotics could enhance some wine characteristics of given ter- roirs in sites a priori not suitable for generating such characteristics.

\section{Terroir zoning on different scales using geospatial technologies}

\subsection{General perspectives}

The differentiation and mapping of regions of grape and wine quality require comprehensive spatial modelling of climatic, soil and agronomical properties, including their changes through time (Vaudour, 2002; Costantini and $\mathrm{Bu}-$ celli, 2014). The construction of such spatial models for demarcating terroir units and predicting their viticultural and wine response is undergoing a methodological revolution as new technologies and analytical methods enable the capturing of detailed spatial and temporal variability of grapevines according to functional properties in the soil. Recent developments in the combined use of several geospatial technologies including geographic information systems (GIS), global positioning systems (GPS), remote sensing (RS) and direct measurements in the field (proxy sensing) are likely to open many new areas in the spatial modelling of winegrowing terroirs. A considerable amount of research dealing with terroir zoning (> 120 journal papers, book chapters and books) has been published since 2002 (Fig. 2). Most of the published research has been carried out on the within-field scale in the context of the so-called "site-specific" or "precision viticulture" (Bramley and Hamilton, 2004; Bramley, 2005; Bramley et al., 2011a, b, c, d, e; Tisseyre and McBratney, 2008; Roudier et al., 2008, 2011; Arnó et al., 2009, 2012; Pedroso et al., 2010), and its median study area covered only 0.12 ha, while between-field studies covering more than $0.11 \mathrm{~km}^{2}$ only represented a quarter of the total (Fig. 3). There is therefore a gap to fill regarding farm $\left(\leq 0.1\right.$ to $\left.1 \mathrm{~km}^{2}\right)$ and district ( $\leq$ some tens of square kilometres) to regional scales ( $\geq$ tens to thousands of square kilometres). The number of map units tends to increase with the log of study area; however, its variation is higher for larger study extents than for within-field studies, and regional studies focus on a larger range of target properties. Twenty or so viticultural, environmental or oenological target properties have been considered over the last decade (Table 1), mainly focusing on grape and canopy characteristics and yield or biomass and secondarily on soil properties on the within-field scale. Table 2 puts together the main recent combination of methods and their pros and cons and references examples to study grape characteristics, canopy, yield, biomass, trunk circumference and/or oenological parameters, vineyard identification, vine rows and vineyard characteristics, vineyard soil properties (or management zones or terroir units), soil surface condition, erosion, and evapotranspiration.

While most former terroir studies dating back the 1970s1990s mainly relied on conventional soil mapping and sparse but very time-consuming soil, vine and grape observations at 
Table 1. Target variables of the zoning studies carried out over the 2002-2013 period (see Fig. 2).

\begin{tabular}{lclclc}
\hline Viticultural & $N$ & Environmental & $N$ & Oenological & $N$ \\
\hline Canopy characteristics & 20 & soil properties & 14 & grape composition & 24 \\
Yield & 17 & oil units & 6 & wine composition & 3 \\
Biomass & 15 & soil surface condition & 3 & wine sensory attributes & 3 \\
Vine water status & 12 & temperatures & 3 & \\
Vineyard identification & 11 & erosion & 3 & \\
Management zones & 8 & climatic zones & 2 & \\
Terroir units & 6 & land use changes & 2 & \\
Pest and weed management & 6 & artificial drainage network & 2 & \\
Evapotranspiration & 4 & landslide & 1 & \\
Vine rows & 4 & & & & \\
Vineyard characteristics & 3 & & & & \\
\hline
\end{tabular}

Legend: $N$, number of papers

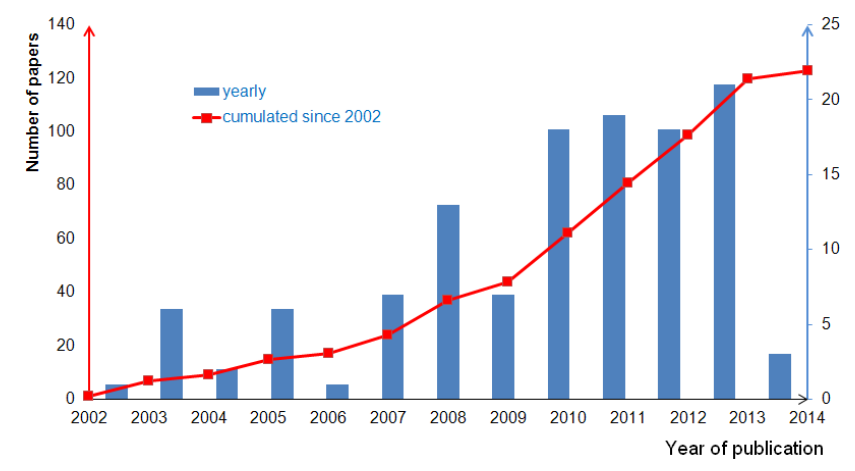

Figure 2. Increase in the number of papers $(N)$ dealing with terroir zoning from 2002 to March 2014. Source: Web of Science (v.5.14, 2014).

field sites, new techniques are promising both for capturing the detailed spatial variability of vineyard areas and for collecting a large amount of soil, vine and grape data. A number of terroir-related studies of the last decade have relied upon a large amount of yield data collected by means of on-the-go yield sensors mounted on mechanical harvesters, which were made commercially available beginning with the 1999 harvest. Pioneering research by Bramley and Hamilton (2004) and Bramley (2005) not only highlighted the magnitude and extent of the spatial variability of yield in some Australian vineyards (of between 4.5 and $7.3 \mathrm{ha}$ ) but also emphasized the significant influence of soils in driving yield differences. The need to assess spatial variations in soil properties has driven the development and application of direct (so-called "proximal") geophysical sensing, particularly for measuring soil apparent electrical conductivity by means of either electrical resistivity surveys and/or electro-magnetic induction scans (EMI) (Lamb et al., 2005; Morari et al., 2009; Taylor et al., 2009; Trought and Bramley, 2011; Fulton et al., 2011; André et al., 2012; Martini et al., 2013; Andrenelli et

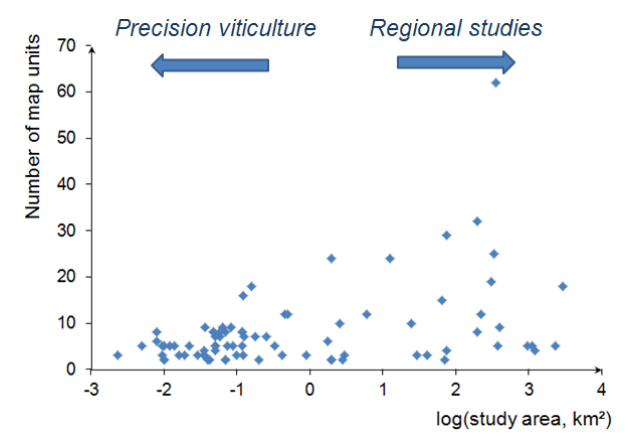

Figure 3. Plot of the number of map units vs. the log of the study area in studies published from 2002 to 2014 (see Fig. 2).

al., 2013; Priori et al., 2013a, b; Rossi et al., 2013; Brillante et al., 2014).

Moreover, the need to assess spatial variation in grapevine biomass and canopy properties, or to map terroir units or to identify vines, has driven the development, acquisition and processing of remote-sensing data. Figure 4 shows that the development of very high spatial resolution airborne acquisitions for the purpose of characterizing grapevine physiological status has represented about one-third of the terroirrelated studies over the last decade (Hall et al., 2002, 2003, 2008; Dobrowski et al., 2003; Lamb et al., 2004; ZarcoTejada et al., 2005; Martín et al., 2007; Gil-Pérez et al., 2010; Meggio et al., 2010; Hall and Wilson, 2013). Most approaches combine several data sources, methods (geostatistical, statistical, image processing, computer vision, mechanistical models) and remote or proxy sensors (Table 2). All approaches use geopositioning devices (not detailed in Table 2) the error positioning requirements of which need to be compatible with the study objectives (i.e. accurate positioning of individual sampled vines) and the spatial resolution of the acquired imagery. 
Table 2. Typology of zoning studies carried out over the 2002-2014 period.

\begin{tabular}{|c|c|c|c|c|c|c|}
\hline Targets & Scale & Data & Methods & Pros & Cons & References (e.g.) \\
\hline \multirow[t]{5}{*}{ Grape composition } & plot & FM & $\begin{array}{l}\text { BK then FA followed by } \\
\text { fuzzy KM }\end{array}$ & Fine-scale & $\begin{array}{l}\text { Time-consuming, high sampling } \\
\text { density }(3 \mathrm{~m})\end{array}$ & Baluja et al. (2013) \\
\hline & plot & FM, airborne NDVI & LR & $\begin{array}{l}\text { Fine-scale spatially } \\
\text { exhaustive data }\end{array}$ & Specific calibration for each plot & $\begin{array}{l}\text { Lamb et al. (2004), } \\
\text { Hall and Wilson (2013) }\end{array}$ \\
\hline & plot & $\begin{array}{l}\text { FM, fluo and/or airborne } \\
\text { NDVI, ChloM }\end{array}$ & Spectral index, CF & $\begin{array}{l}\text { Replaces expensive } \\
\text { measurements }\end{array}$ & $\begin{array}{l}\text { Need for specific calibration for } \\
\text { each plot? }\end{array}$ & $\begin{array}{l}\text { Ben Ghozlen et al. (2010), Baluja et } \\
\text { al. (2012b), Agati et al. (2013) }\end{array}$ \\
\hline & district & $\begin{array}{l}\text { VIS-NIR } \\
\text { borne/UAV } \\
\text { FM }\end{array}$ & Spectral indices, LR & $\begin{array}{l}\text { Fine-scale spatially } \\
\text { exhaustive data }\end{array}$ & Specific calibration for each plot & $\begin{array}{l}\text { Martín et al. (2007), } \\
\text { Meggio et al. (2010) }\end{array}$ \\
\hline & region & $\begin{array}{l}\text { FM, VIS-NIR-SWIR HR } \\
\text { satellite imagery, TopoP } \\
\text { and/or soil map and/or } \\
\text { SPE }\end{array}$ & Multitemporal SC, SA & $\begin{array}{l}\text { Large-scale spatially ex- } \\
\text { haustive data, landscape- } \\
\text { scale relevant for unions of } \\
\text { winegrowers }\end{array}$ & $\begin{array}{l}\text { Spatial resolution of imagery ap- } \\
\text { propriate if there is homogeneity of } \\
\text { practices }\end{array}$ & $\begin{array}{l}\text { Vaudour (2003), } \\
\text { Vaudour et al. (2010, 2014a) }\end{array}$ \\
\hline \multirow[t]{8}{*}{$\begin{array}{l}\text { Canopy } \\
\text { characteristics, yield and } \\
\text { grape composition }\end{array}$} & plot & FM, YM & $\begin{array}{l}\text { OK then KM and/or } \\
\text { LOGR and/or NPT }\end{array}$ & Fine-scale & $\begin{array}{l}\text { Time-consuming, high sampling } \\
\text { density }(2 \mathrm{~m})\end{array}$ & $\begin{array}{l}\text { Bramley and Hamilton (2004), } \\
\text { Bramley (2005), Tisseyre et al. } \\
\text { (2008), } \\
\text { Bramley et al. (2011a), Arnó et al. } \\
(2012)\end{array}$ \\
\hline & plot & $\begin{array}{l}\text { FM (including CC), soil } \\
\text { ECa, TopoP }\end{array}$ & $\begin{array}{l}\text { NDVI, Fuzzy KM, corre- } \\
\text { lations }\end{array}$ & Fine-scale & Need for further validation & Tagarakis et al. (2013) \\
\hline & plot & $\begin{array}{l}\text { FM, VHSR satellite } \\
\text { NDVI }\end{array}$ & $\begin{array}{l}\text { Fuzzy KM and/or GK, } \\
\text { ANOVA and/or PCA } \\
\text { and/or NPT }\end{array}$ & $\begin{array}{l}\text { Early grape composition, } \\
\text { definition of harvest zones }\end{array}$ & $\begin{array}{l}\text { Spatial resolution of imagery not } \\
\text { quite appropriate? }\end{array}$ & $\begin{array}{l}\text { Martínez-Casanovas et al. (2012), } \\
\text { Urretavizcaya et al. (2013) }\end{array}$ \\
\hline & plot & $\begin{array}{l}\text { FM, airborne NDVI } \\
(0.3 \mathrm{~m})\end{array}$ & Correlations & $\begin{array}{l}\text { Easy-to-use, spatially } \\
\text { exhaustive data }\end{array}$ & Specific calibration for each plot & Hall et al. (2011) \\
\hline & farm & $\begin{array}{l}\text { FM (including } \delta^{13} \mathrm{C} \text { ), air- } \\
\text { borne NDVI, soil ECa, } \\
\text { TopoP }\end{array}$ & $\begin{array}{l}\text { WHC, ANOVA, IDW } \\
\text { thresholding }\end{array}$ & $\begin{array}{l}\text { Relevant scale for winery, } \\
\text { good compromise data col- } \\
\text { lection and results }\end{array}$ & $\begin{array}{l}\text { Need to test feasibility on the win- } \\
\text { ery scale }\end{array}$ & Santesteban et al. (2013) \\
\hline & $\begin{array}{l}\text { farm/ } \\
\text { district }\end{array}$ & $\begin{array}{l}\text { FM (LAI), VHSR satellite } \\
\text { NDVI }\end{array}$ & LR & $\begin{array}{l}\text { Easy-to-use, spatially } \\
\text { exhaustive data }\end{array}$ & $\begin{array}{l}\text { Specific calibration for each image, } \\
\text { spatial resolution of imagery not } \\
\text { adapted to every viticultural system }\end{array}$ & Johnson et al. (2003) \\
\hline & district & $\begin{array}{l}\text { VIS-NIR HypS airborne } \\
\text { imagery, FM (including } \\
\text { leaf LabR spectra) }\end{array}$ & $\begin{array}{l}\text { LR, spectral indices, in- } \\
\text { version of PROSPECT- } \\
\text { rowRCRM model for pre- } \\
\text { dicting leaf reflectance }\end{array}$ & $\begin{array}{l}\text { Fine-scale spatially } \\
\text { exhaustive data }\end{array}$ & Complex parameterization & Zarco-Tejada et al. $(2005,2013)$ \\
\hline & region & $\begin{array}{l}\text { FM, soil map, TopoP, } \\
\text { daily climatic data }\end{array}$ & SWAP mechanistic model & $\begin{array}{l}\text { Landscape-scale relevant } \\
\text { for unions of winegrowers }\end{array}$ & $\begin{array}{l}\text { Needs detailed data at specific sites } \\
\text { for parameterization }\end{array}$ & Bonfante et al. (2011) \\
\hline $\begin{array}{l}\text { Yield, oenological } \\
\text { parameters }\end{array}$ & plot & $\begin{array}{l}\text { FM, YM, soil ER, } \\
\text { airborne NDVI and/or to- } \\
\text { pographic parameters }\end{array}$ & OK and/or PCA then KM & $\begin{array}{l}\text { Fine-scale, whole soil- } \\
\text { vine-wine chain consid- } \\
\text { ered }\end{array}$ & $\begin{array}{l}\text { Time-consuming, high sampling } \\
\text { density }(\leq 2 \mathrm{~m}) \text {, multisensor collec- } \\
\text { tion, microvinifications }\end{array}$ & $\begin{array}{l}\text { Bramley et al. (2011c, d), } \\
\text { Priori et al. (2013b) }\end{array}$ \\
\hline $\begin{array}{l}\text { Biomass, oenological } \\
\text { parameters }\end{array}$ & plot & FM, airborne NDVI & $\begin{array}{l}\text { NDVI thresholding, then } \\
\text { LR }\end{array}$ & Fine-scale & $\begin{array}{l}\text { Time-consuming, high sampling } \\
\text { density }(5 \mathrm{~m})\end{array}$ & Fiorillo et al. (2012) \\
\hline $\begin{array}{l}\text { Yield, vine trunk } \\
\text { circumference }\end{array}$ & plot & FM, soil ER, TopoP & LR, Fuzzy KM, ANOVA & Fine-scale & Time-consuming data collection & Rossi et al. (2013) \\
\hline $\begin{array}{l}\text { Vine trunk } \\
\text { circumference, manage- } \\
\text { ment zones }\end{array}$ & farm & FM, airborne NDVI & Spatially constrained KM & Manageable zones & $\begin{array}{l}\text { Need for effective testing of the ag- } \\
\text { gregation component of the algo- } \\
\text { rithm }\end{array}$ & Pedroso et al. (2010) \\
\hline \multirow[t]{5}{*}{ Vine water status } & plot & $\begin{array}{l}\text { FM (including PLWP), } \\
\text { airborne NDVI }\end{array}$ & $\begin{array}{l}\text { NDVI thresholding, } \\
\text { LCCAOT }\end{array}$ & $\begin{array}{l}\text { Temporal stability of the } \\
\text { zoning over } 3 \text { years }\end{array}$ & $\begin{array}{l}\text { One soil type considered, specific } \\
\text { calibration for each block required }\end{array}$ & Acevedo-Opazo et al. (2010a) \\
\hline & plot & $\begin{array}{l}\text { FM (including } \delta^{13} \mathrm{C} \text { and } \\
\text { SWP) }\end{array}$ & $\begin{array}{l}\text { LR, NPT, LCCAOT, IDW } \\
\text { thresholding }\end{array}$ & $\begin{array}{l}\text { High validation } \\
\text { performance }\end{array}$ & $\begin{array}{l}\text { Specific calibration for each block } \\
\text { required }\end{array}$ & Herrero-Langreo et al. (2013) \\
\hline & plot & $\begin{array}{l}\text { FM (PLWP or SWP), } \\
\text { VIS-NIR MS and thermal } \\
\text { UAV imagery }\end{array}$ & Spectral indices, LR & & $\begin{array}{l}\text { Specific calibration for each plot re- } \\
\text { quired }\end{array}$ & $\begin{array}{l}\text { Baluja et al. (2012a), } \\
\text { Bellvert et al. (2014) }\end{array}$ \\
\hline & farm & $\begin{array}{l}\text { FM (including PLWP), } \\
\text { airborne NDVI, soil ER }\end{array}$ & $\begin{array}{l}\text { NDVI thresholding, PCA, } \\
\text { NPT }\end{array}$ & $\begin{array}{l}\text { Temporal stability of the } \\
\text { zoning over } 3 \text { years }\end{array}$ & $\begin{array}{l}\text { Auxiliary information on soil types } \\
\text { needed }\end{array}$ & Acevedo-Opazo et al. (2008) \\
\hline & district & FM (PLWP) & LCCAOT, LR & $\begin{array}{l}\text { Easy to apply for } \\
\text { winegrowers }\end{array}$ & Need for further validation & Baralon et al. (2012) \\
\hline Vine rows & plot & Airborne NDVI & VineCrawler algorithm & $\begin{array}{l}\text { Suited for vineyards with } \\
\text { large rows and inter-rows }\end{array}$ & $\begin{array}{l}\text { Not suited for dense low-vigour } \\
\text { vineyards with missing vines }\end{array}$ & Hall et al. (2003) \\
\hline \multirow{6}{*}{$\begin{array}{l}\text { Vineyard identification, } \\
\text { vine rows, and vineyard } \\
\text { characteristics }\end{array}$} & plot & $\begin{array}{l}\text { FM (LAI), VIS multian- } \\
\text { gular UAV imagery }\end{array}$ & SfM, multiple regression & $\begin{array}{l}\text { Promising; } \\
\text { 3-D reconstruction }\end{array}$ & $\begin{array}{l}\text { Big data; further improvements } \\
\text { needed to improve LAI prediction }\end{array}$ & Matthews and Jensen (2013) \\
\hline & district & $\begin{array}{l}\text { VIS-NIR MS ULM or air- } \\
\text { borne imagery }\end{array}$ & $\begin{array}{l}\text { TA, FT and/or "object- } \\
\text { classifier" }\end{array}$ & $\begin{array}{l}\text { Easy implementation, high } \\
\text { processing speed, limited } \\
\text { amount of parameters, ex- } \\
\text { port into GIS shapefile for- } \\
\text { mat }\end{array}$ & $\begin{array}{l}\text { Further validation needed for de- } \\
\text { tecting missing plants, further use } \\
\text { of all spectral information }\end{array}$ & $\begin{array}{l}\text { Rabatel et al. (2008), Delenne et al. } \\
(2008,2010) \text {, Puletti et al. (2014) }\end{array}$ \\
\hline & district & FM, airborne lidar & $\begin{array}{l}\text { Georeferencing, LR } \\
\text { and/or KM, TA }\end{array}$ & $\begin{array}{l}\text { Powerful, } \\
\text { 3-D reconstruction }\end{array}$ & $\begin{array}{l}\text { Need for further tests on complex } \\
\text { viticultural landscapes with several } \\
\text { training modes? Cost-prohibitive } \\
\text { repeated acquisitions }\end{array}$ & $\begin{array}{l}\text { Llorens et al. (2011), Matthews and } \\
\text { Jensen (2012) }\end{array}$ \\
\hline & region & $\begin{array}{l}\text { VIS MS helicopter } \\
\text { imagery }\end{array}$ & FT, TA & $\begin{array}{l}\text { Robust recognition of } \\
\text { vineyards }\end{array}$ & $\begin{array}{l}\text { Ambiguities in identifying training } \\
\text { modes }\end{array}$ & Wassenaar et al. (2002) \\
\hline & region & $\begin{array}{l}\text { VHSR MS satellite } \\
\text { imagery }\end{array}$ & $\begin{array}{l}\text { TA, autocorrelogram } \\
\text { pattern }\end{array}$ & $\begin{array}{l}\text { Robust recognition of } \\
\text { vineyards }\end{array}$ & $\begin{array}{l}\text { Better adapted to equally spaced } \\
\text { vineyards with large rows }\end{array}$ & Warner and Steinmaus (2005) \\
\hline & region & MR MS satellite imagery & Multitemporal SC & $\begin{array}{l}\text { Fast unexpensive } \\
\text { landscape-scale map }\end{array}$ & $\begin{array}{l}\text { Not accurate enough on the } \\
\text { farm or plot scales }\end{array}$ & $\begin{array}{l}\text { Lanjeri et al. (2004), } \\
\text { Rodríguez-Pérez et al. (2008) }\end{array}$ \\
\hline
\end{tabular}


Table 2. Continued.

\begin{tabular}{|c|c|c|c|c|c|c|}
\hline Targets & Scale & Data & Methods & Pros & Cons & References (e.g.) \\
\hline \multirow[t]{5}{*}{$\begin{array}{l}\text { Soil properties, potential } \\
\text { management zones }\end{array}$} & plot & $\begin{array}{l}\text { Soil ECa and/or ER, FM } \\
\text { (soil analysis) and/or air- } \\
\text { borne and satellite NDVI }\end{array}$ & FKA, KM & $\begin{array}{l}\text { Additional description of } \\
\text { residual variation within } \\
\text { classes provided }\end{array}$ & $\begin{array}{l}\text { Ground-truth soil samples manda- } \\
\text { tory to understand and interpret } \\
\text { EMI mapping }\end{array}$ & $\begin{array}{l}\text { Morari et al. (2009), André et al. } \\
\text { (2012), Andrenelli et al. (2013), } \\
\text { Martini et al. (2013), Priori et al. } \\
\text { (2013a) }\end{array}$ \\
\hline & farm & Soil ECa, soil map & $\begin{array}{l}\text { Geostatistical descriptors, } \\
\text { FA }\end{array}$ & $\begin{array}{l}\text { Satisfactory discrimination } \\
\text { between soil types }\end{array}$ & $\begin{array}{l}\text { Reference soil map needed in addi- } \\
\text { tion to ECa }\end{array}$ & Taylor et al. (2009) \\
\hline & region & $\begin{array}{l}\text { FM (clay content), air- } \\
\text { borne VIS-NIR-SWIR } \\
\text { HypS imagery }\end{array}$ & $\mathrm{CR}, \mathrm{CoK}, \mathrm{BcoK}$ & Spatially validated & $\begin{array}{l}\text { Further test on other soil } \\
\text { types or cultural practices }\end{array}$ & Lagacherie et al. (2012) \\
\hline & region & $\begin{array}{l}\text { FM (soil types, analyses), } \\
\text { TopoP, geological map, } \\
\text { soil map and/or climatic } \\
\text { data }\end{array}$ & $\begin{array}{l}\text { GIS combination of raster } \\
\text { layers and/or PCA and/or } \\
\text { KM }\end{array}$ & $\begin{array}{l}\text { Landscape-scale relevant } \\
\text { for unions of winegrowers }\end{array}$ & $\begin{array}{l}\text { Need for further spatial validation; } \\
\text { potential high number of output } \\
\text { map units }\end{array}$ & $\begin{array}{l}\text { Carey et al. (2008), } \\
\text { Herrera-Nuñez et al. (2011) }\end{array}$ \\
\hline & region & $\begin{array}{l}\text { FM (soil types, analyses), } \\
\text { TopoP and/or satellite HR } \\
\text { imagery }\end{array}$ & $\begin{array}{l}\text { Different geostatistical } \\
\text { models, SC, PCA, fuzzy } \\
\text { KM }\end{array}$ & $\begin{array}{l}\text { Landscape-scale relevant } \\
\text { for unions of winegrowers; } \\
\text { spatially validated }\end{array}$ & $\begin{array}{l}\text { Need for further viticultural charac- } \\
\text { terization } \\
\text { and validation }\end{array}$ & $\begin{array}{l}\text { Hugues et al. (2012), Malone et } \\
\text { al. (2014), Priori et al. (2014) }\end{array}$ \\
\hline \multirow[t]{2}{*}{ Soil surface condition } & plot & $\begin{array}{l}\text { FM (soil infiltration rate, } \\
\text { clod sizes), VIS UAV im- } \\
\text { agery }\end{array}$ & $\begin{array}{l}\text { SC, multiscale "object- } \\
\text { classifier" }\end{array}$ & $\begin{array}{l}\text { Allows avoiding time- } \\
\text { consuming field descrip- } \\
\text { tions }\end{array}$ & $\begin{array}{l}\text { Possible improvements considering } \\
\text { NIR and SWIR ranges }\end{array}$ & Corbane et al. (2008b , 2012) \\
\hline & region & $\begin{array}{l}\text { FM (BRDF), VIS } \\
\text { helicopter imagery }\end{array}$ & TA, BRDF model & $\begin{array}{l}\text { Extraction of bare soil } \\
\text { inter-rows }\end{array}$ & $\begin{array}{l}\text { Possible improvements considering } \\
\text { NIR and SWIR ranges; need for } \\
\text { further validation }\end{array}$ & Wassenaar et al. (2005) \\
\hline \multirow[t]{2}{*}{ Erosion } & plot & $\begin{array}{l}\text { FM (SUM), TopoP, histor- } \\
\text { ical land use maps and/or } \\
\text { soil ER, and/or VIS UAV } \\
\text { imagery }\end{array}$ & KM, multitemporal SA & $\begin{array}{l}\text { Fine-scale spatially } \\
\text { exhaustive data }\end{array}$ & $\begin{array}{l}\text { Further developments on a higher } \\
\text { scale; time-consuming observations }\end{array}$ & $\begin{array}{l}\text { Brenot et al. (2008), Paroissien } \\
\text { et al. (2010), Chevigny et al. } \\
\text { (2014), Quiquerez et al. (2014) }\end{array}$ \\
\hline & region & $\begin{array}{l}\text { FM (SUM), TopoP, histor- } \\
\text { ical land use information }\end{array}$ & multitemporal SA & $\begin{array}{l}\text { Variability of } \\
\text { multi-decennial erosion } \\
\text { across local and regional } \\
\text { scales with acceptable } \\
\text { investigation } \\
\text { costs }\end{array}$ & Time-consuming observations & Paroissien et al. (2010) \\
\hline Evapotranspiration & region & $\begin{array}{l}\text { FM (EdCov, soil water), } \\
\text { VIS-NIR-SWIR-thermal } \\
\text { satellite imagery }\end{array}$ & $\begin{array}{l}\text { HYDRUS-1D model, } \\
\text { S-SEBI and WBI models }\end{array}$ & $\begin{array}{l}\text { accuracies between } \\
0.8 \mathrm{~mm} \mathrm{~d}^{-1} \text { and } \\
1.1 \mathrm{~mm} \mathrm{~d}^{-1} \text { compatible } \\
\text { with applications }\end{array}$ & $\begin{array}{l}\text { Further need to address model sen- } \\
\text { sitivities, inclusion of row orienta- } \\
\text { tion, landscape characterization }\end{array}$ & Galleguillos et al. (2011a, b) \\
\hline
\end{tabular}

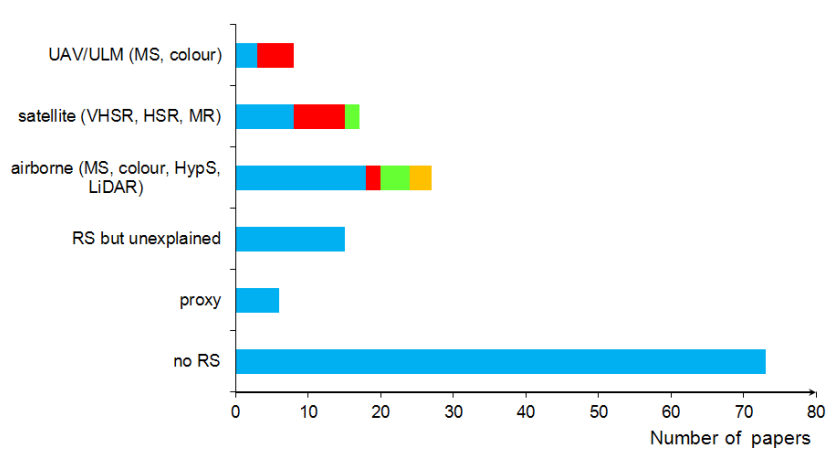

Figure 4. Use of remote-sensing devices for the purpose of terroir zoning from 2002 to March 2014. Source: Web of Science (v.5.14). UAV - unmanned aerial vehicle; ULM - ultra-light motorized; MS - multispectral; VHSR - very high spatial resolution; HSR - high spatial resolution; MR - medium resolution; HypS - hyperspectral. "Proxy" here means reflectance measurements and/or crop circle NDVI and not geophysical measurements.

\subsection{Remote sensing of terroir}

The use of remote-sensing data in the context of defining terroir and/or within-field management zones in the last decade has given rise to either straightforward use of spectral indices aimed at characterizing vigour or physiological condition (e.g. Hall et al., 2003; Johnson et al., 2003; Lamb et al., 2004; Zarco-Tejada et al., 2005; Rodríguez-Pérez et al., 2007; Hall and Wilson, 2013) and grape quality (Martín et al., 2007; Martínez-Casasnovas et al., 2012; Primicerio et al., 2012), or more sophisticated image processing aimed at either mapping terroir units (Pedroso et al., 2010; Vaudour et al., 2010; Urretavizcaya et al., 2013) or identifying vineyards (e.g. Wassenaar et al., 2002; Warner and Steinmaus, 2005; Rabatel et al., 2006, 2008; Delenne et al., 2008, 2010) (Tables 1 and 2). Other remote-sensing studies have dealt with the incorporation of remote-sensing information into the prediction of soil properties and their monitoring in vineyards (Vaudour, 2008; Corbane et al., 2012; Lagacherie et al., 2012), with the assessment of soil erosion patterns (Quiquerez et al., 2014; Chevigny et al., 2014) or with the prediction of vineyard evapotranspiration (Galleguillos et al., 2011a, b; Bellvert et al., 2014). 


\subsubsection{Use of vegetation indices for assessing vine vigour and physiology: the NDVI}

Typically, the information retrieved from remote sensing has solely relied on the calculation of the most commonly used normalized difference vegetation index (NDVI) defined by Eq. (1) (Tucker, 1979) from images acquired at or near veraison.

$\mathrm{NDVI}=\frac{\left(R_{\mathrm{NIR}}-R_{\mathrm{R}}\right)}{\left(R_{\mathrm{NIR}}+R_{\mathrm{R}}\right)}$,

where $R_{\text {NIR }}$ is reflectance in the near infrared spectral band and $R_{\mathrm{R}}$ is reflectance in the red spectral band.

Providing a number between -1 and +1 , quantifying the relative difference between the near infrared reflectance "peak" of vegetation tissues and the red reflectance "trough" due to chlorophyll and carotenoids pigment absorption, the NDVI is the most widely used indicator of plant canopy vigour and relates to the leaf area index (LAI: the ratio of leaf surface area to ground area), fractional cover, biomass, shaded area (Hall et al., 2002, 2003; Johnson, 2003; Johnson et al., 2003; Dobrowski et al., 2008) and grape quality (Fiorillo et al., 2012). In very high spatial resolution (VHSR) vineyard imagery, canopy-only pixels tend to have very high NDVI values, commonly ranging between 0.75 and 0.85 (Hall et al., 2002, 2003, 2008). Interpretation of NDVI threshold values requires adaptation to each case study region. This is because typical multispectral images with coarser resolution, such as $4 \mathrm{~m}$ IKONOS, may have values that integrate mixed signals from both vine row and interrow and from either bare soil or soil vegetated with an interrow crop. However, many studies do not give sufficient detail on the retrieval of NDVI, which basically requires that the digital numbers of the raw images be atmospherically corrected to surface reflectance values prior to NDVI computation in order to minimize differences in light conditions (Vaudour et al., 2014b). In an attempt to address the issue of variable environmental conditions when acquiring multitemporal imagery, the digital numbers are either normalized (e.g. Vaudour et al., 2010) or alternatively sliced into high, medium and low values for each image (e.g. Dobrowski et al., 2003). However, more often than not the relationships between NDVI and grapevine vegetation and terroir parameters are assessed on an individual image basis, using raw digital numbers (e.g. Johnson et al., 2003; Lamb et al., 2004) or even ignoring atmospheric effects. Using airborne hyperspectral sensors, such as the Compact Airborne Spectrographic Imager (CASI), the Reflective Optics Imaging Spectrometer (ROSIS) and the Digital Airborne Imaging Spectrometer (DAIS-7915), and atmospherically corrected images, Zarco-Tejada et al. (2005) demonstrated that narrowband hyperspectral indices in the $700-750 \mathrm{~nm}$ spectral region performed better than NDVI for the purpose of estimating the chlorophyll content of leaves and then detecting iron deficiency chlorosis. Using the airborne hyperspectral scanner
(AHS) at a $1000 \mathrm{~m}$ altitude flight providing a spatial resolution of $2.5 \mathrm{~m}$, Meggio et al. (2010) devised other physiological indices for predicting carotenoid and anthocyanin leaf contents, which were related to grape quality in a previous study (Martín et al., 2007).

\subsubsection{Identification and/or characterization of vineyards}

Some researchers have developed change detection classifications in order to extract regional land use changes including vineyards from multidate, multispectral images with a medium spatial resolution, such as $30 \mathrm{~m}$ Landsat data (Lanjeri et al., 2004; Rodriguez-Pérez et al., 2007; Manandhar et al., 2010). However, much of the work in this area over the last decade is especially influenced by the advent of VHSR images, which have favoured innovative approaches for retrieving specific patterns of vineyard arrangements from helicopter colour images with $\sim 0.25 \mathrm{~m}$ resolution (Wassenaar et al., 2002), airborne multispectral images with $\sim 2 \mathrm{~m}$ resolution (Gong et al., 2003) or $0.5 \mathrm{~m}$ resolution (Rabatel et al., 2006), satellite panchromatic $1 \mathrm{~m}$ IKONOS images (Warner and Steinmaus, 2005), satellite panchromatic $0.6 \mathrm{~m}$ Quickbird images (Rabatel et al., 2006), and ultra-light motorized (ULM) colour $0.5 \mathrm{~m}$ images (Rabatel et al., 2008; Delenne et al., 2010). Approaches for vineyard identification include grapevine field detection (Wassenaar et al., 2002; Rabatel et al., 2006), grapevine field delineation (Da Costa et al., 2007), grapevine row extraction (Hall et al., 2003; Delenne et al., 2010; Matthews and Jensen, 2013; Puletti et al., 2014) and the detection of missing plants (Chanussot et al., 2005; Delenne et al., 2010). These approaches have mostly used greylevel images (often the red band) and either relied on frequency analysis (Wassenaar et al., 2002; Rabatel et al., 2006; Delenne et al., 2010) or developed textural analysis, a branch of image processing focused on the spatial statistics of the grey levels of images, the variations of which are perceived as homogeneous areas by the human eye (Haralick et al., 1973). The textural analysis is based on co-occurrence matrices, i.e. "the histogram, in a given neighbourhood for each pixel (e.g. $7 \times 7$ ), of the grey-level transitions when considering a given translation in a given direction, from which various parameters can be computed", for instance energy, correlation, directivity, entropy and contrast (Rabatel et al., 2006). Provided that the boundaries of each field are available, one can apply a local Fourier transform to extract information on the type of vineyard planting as well as crop spacing and orientation (Wassenaar et al., 2002) or isolate each individual field by selecting the corresponding frequencies in the Fourier spectrum using a specific Gabor filter applied recursively (Rabatel et al., 2008; Delenne et al., 2010). Another approach is that of spatial autocorrelation, requiring that grapevines be equally spaced and that the spatial resolution be fine enough that individual grapevines are distinguished from one another (Warner and Steinmaus, 2005). 


\subsubsection{Characterization of soil types, soil properties, soil surface condition and erosion}

As vineyard inter-rows are frequently left bare, particularly in Mediterranean regions, remote-sensing satellite images acquired in spring, before budburst, have been used for the purpose of mapping soil surface type and condition. For instance, high-resolution multispectral $20 \mathrm{~m}$ SPOT images during spring have been processed using a supervised Bayesian maximum likelihood classifier to map red Mediterranean soils originating from Plio-Pleistocene fluvial deposits in the Southern Rhône Valley, with an overall accuracy of 60-70\% (Vaudour, 2008). Being important factors in runoff and infiltration processes, soil surface characteristics (SSCs) have been mapped on the within-field scale using VHSR images with $0.1 \mathrm{~m}$ resolution acquired by means of unmanned aerial vehicles (UAVs) equipped with a colour camera: Pixy ${ }^{\circledR}$ (Corbane et al., 2008a, b) or DRELIO ${ }^{\circledR}$ (Quiquerez et al., 2014). Depending on SSC classes and surface conditions, overall accuracy ranged from 63 to $84 \%$ (Corbane et al., 2008b). The clay content of viticultural soils of the La Peyne catchment in Languedoc (southern Mediterranean France) has been successfully estimated from the $2206 \mathrm{~nm}$ wavelength of an airborne hyperspectral HyMap ${ }^{\circledR}$ image with $5 \mathrm{~m}$ spatial resolution and then spatially predicted from a co-kriging model using this image as a co-variable (Lagacherie et al., 2012).

\subsubsection{Incorporation of remote-sensing information into the spatial modelling of terroirs}

Remote-sensing images have been used for the purpose of mapping terroir units on regional scales, facilitating the selection of plant material, the assemblage of harvest and the monitoring of vine phenology and status across a number of individual fields spread over a regional viticultural area. A terroir concept adapted to spatial modelling from remote sensing considers soil landscape units as base elements for defining terroir units, jointly with climate series and grape composition series (Vaudour, 2003). A soil landscape, also referred to as a soilscape (Hole, 1978) or "pédopaysage" (Girard, 1983), can be defined as a landscape unit including a limited number of soil classes that are geographically distributed according to an identifiable pattern (Lagacherie et al., 2001). Soil landscape units were also defined as "a set of pedological horizons and landscape features (vegetation, effects of human activities, geomorphology, hydrology and parent material) whose spatial organization allows for defining a soil mantle (or a subset of it)" (Girard, 1983; Carré and Girard, 2002). Their identifiable pattern can be retrieved from the visual interpretation of several geographical data layers including image classification results and stereoscopic photograph examination (Vaudour et al., 1998; Vaudour, 2003). The visual interpretation process follows a set of rules describing a conceptual model of soil landscape organization, which relies on the assumption that soil landscape units may be inferred from the geomorphological identification of surficial formations (e.g. mainly glacio-fluvial terraces in the Rhône Valley), the age and relative elevation of which correspond to distinct durations of pedogenesis ("fersiallitization") and thus distinct soil layer depths and properties, including soil surface stoniness and colour (Vaudour, 2008). In this pioneering approach, visual interpretation was digitally performed within a GIS along with the description and recording of several soil landscape attributes at each delineated polygon area. Potential terroir units were then obtained from the Ward's clustering of these soil landscape attributes and were further validated against a considerable set of grape composition data spanning 17 years. In an attempt to reduce the time-consuming stage of visual interpretation, alternate approaches which solely relied on the automatic processing of remote-sensing and/or morphometric data were proposed, either based on combining per-pixel and textural classifiers (Vaudour, 2003) or on bootstrapped regression trees (Vaudour et al., 2010). In these studies, the resulting map units were termed "terroir" and "viticultural" because they were tested against a considerable set of grape composition data over a long-term period (Vaudour et al., 1998; Vaudour, 2003) or relied on $\sim 50$ reference vineyards, the oenological properties of which were known from previous research (Vaudour et al., 2010). In another study, the spatial units of which were termed "terrons", because they were not tested again viticultural data (Hughes et al., 2012; Malone et al., 2014), Landsat bands and several Landsat band ratios including NDVI were included as covariates of soil profile data in a number of geostatistical models in order to spatially predict several soil properties. These properties include soil $\mathrm{pH}$, clay percentage, soil mineralogy (clay types and presence of iron oxides), continuous soil classes and the presence or absence of marl, the predicted soil properties were then combined with landscape attributes (derived from a digital elevation model) through fuzzy $k$-means in order to predict 10 non-marl "terron units" and 2 marl "terron units" depending on the presence of marl (i.e. active lime) at $0.5 \mathrm{~m}$ depth. Such an approach to defining "terrons" was initially proposed by Carré and McBratney (2005) and is meant as an initial stage prior to defining viticultural terroirs. A similar study using the term "natural terroir units" and derived from the geostatistical methods described by Castrignanò et al. (2009) was carried out in Tuscany but did not include remote-sensing layers (Priori et al., 2014). "Natural terroir units" (NTU) were first proposed by Laville (1990), as "a volume of the Earth's biosphere that is characterized by a stable configuration and values of the environmental factors", and built from morphometric data and lithological units.

Because of the data availability, topography, climate, substrate and soil are the most commonly used land features in digital terroir zoning (e.g. Carey et al., 2008; Herrera-Nuñez et al., 2011). In fact, there is a conceptual similarity, if not a direct relationship, between the NTU as constructed by Priori 
et al. (2014) (see Sect. 3.3.3), terron units and soil landscape units.

On the within-field scale, "management zones" originating from a set of soil and/or vegetation proxy and remotely sensed attributes, typically NDVI, were also obtained using either fuzzy $k$-means (Bramley and Hamilton, 2004; Pedroso et al., 2010; Taylor et al., 2013; Tagarakis et al., 2013; Priori et al., 2013b; Urretavizcaya et al., 2013) or Ward's clustering (Santesteban et al., 2013). Similar clustering approaches have been performed using a multivariate set of spatial layers, including apparent electrical conductivity but without remote-sensing images (e.g. Martini et al., 2013).

In order to be applicable in an operational manner, management zones need (Bramley and Hamilton, 2004) (i) to provide stable, constant patterns from year to year; (ii) be related to yield; (iii) be manageable; and (iv) be more economically beneficial than conventional uniform management. An objection to using remote-sensing images for delineating management zones is that they "provide only a within-season snapshot and may not relate to final crop yield" (Taylor et al., 2007). According to Tisseyre et al. (2008), later confirmed by Trought and Bramley (2011), "yield or vigour (pruning weight, size of the canopy) maps of the previous years are relevant in designing site-specific management strategies in the year " $n+1$ " and subsequent years" and conversely in producing maps of quality parameters (sugar content, titratable acidity, $\mathrm{pH}$ ) which present no temporal stability of withinfield variability. This is in compliance with the observations made previously on the regional scale, in the terroir units mapped in the Southern Rhône Valley, for which a long-term frequency analysis of Grenache berry composition had highlighted a strong vintage interaction and no temporal stability of berry composition groups (Vaudour, 2003). When acquired over bare soils in spring, multispectral SPOT images showed a high temporal stability for deriving homogeneous terroir zones (Vaudour, 2008) which matched those obtained from the supervised support vector machine classifier of a single-year within-season SPOT4 Take 5 time series acquired from February to June and accounting for vegetation vigour and phenology (Vaudour et al., 2014a). In order to account for the between-terroir variation in grass vegetation across seasons in vineyards with grass intercrops, regional terroir units may be retrieved from multitemporal multi-seasonal images (Vaudour et al., 2010).

On the within-field scale, while unsupervised clustering algorithms are commonly used for defining viticultural management zones, other methods have been proposed for cerealgrowing systems (e.g. Roudier et al., 2008) in order to address the problem of the manageability of the mapped zones. These authors emphasized the distinction between classification methods, which define classes, such as groups of individual pixels presenting similar properties, and segmentation methods, which define regions or the expression of those groups in space and time and form individual patches. They proposed using a segmentation method stemming from mathematical morphology and applying the watershed algorithm initially proposed by Beucher and Lantuéjoul (1979) and later formalized by Vincent and Soille (1991). They suggested an approach for reducing the over-segmentation of zones, the number of which was selected following Lark's parsimony principle (2001). According to this principle, the most suitable number of clusters is that "after which the vegetation parameter (such as biomass) variance reduction remains more or less constant or declines more slowly" (Roudier et al., 2008). Generally, the number of within-field zones effectively chosen is empirically defined, comprises between 3 and 5 zones and, when illustrated through raster monovariate maps, is eventually described through up to 20 map units based on equal-distance or equal-density intervals (Fig. 3). Pedroso et al. (2010) proposed another withinfield segmentation approach based on a contextual colour and shape criterion and performed on an NDVI airborne ADS40 image with $5 \mathrm{~m}$ resolution; they aimed at optimizing variance partitioning of vine circumference data and removing small unmanageable polygons covering less than 0.1 ha.

Zoning based on automatic procedures should also enable us to assess prediction error and/or error uncertainty along with predictions. In the approach devised by Pedroso et al. (2010), the effectiveness of the management unit delineations was determined from the adjusted $R^{2}$ from ANOVA using the management units as the independent variable and grapevine circumference data as the dependent variable. Most terroir units or management zones are validated following a similar variance testing procedure, i.e. demonstrating how well delineation explains a key growth, grape or berry composition parameter (e.g. Priori et al., 2013b; Santesteban et al., 2013). However, while the agronomical and soil property model is verified and/or validated, its spatial prediction error is not, or only seldom, assessed except for geostatistical approaches (Castrignanò et al., 2009; Lagacherie et al., 2012) and for the bootstrapped approach by Vaudour et al. (2010).

\subsubsection{Prediction of evapotranspiration and management of irrigation on the basis of remote-sensing information}

Recent developments of remote-sensing applications in terroir-related studies have dealt with the prediction of evapotranspiration using multispectral Advanced Spaceborne Thermal Emission and Reflection Radiometer (ASTER) images through the thermal infrared bands with $90 \mathrm{~m}$ resolution (Galleguillos et al., 2011a, b). Using the approach developed by Galleguillos et al. (2011a, b) and a linear downscaling based on land use at smaller pixel sizes, Taylor et al. (2013) demonstrated that the ASTER-derived evapotranspirationbased covariates were of particular significance in the soil depth modelling while water table depth was better explained by models that used digital terrain attributes at smaller pixel sizes. 


\subsubsection{Contribution of lidar and UAV remote sensing}

The use of UAVs in precision viticulture is very recent and promising, as the time of acquisition is tightly controlled and adapted to the user's needs. In particular, promising approaches to mapping vine water stress were presented by Baluja et al. (2012a) and by Bellvert et al. (2014), based on $0.3 \mathrm{~m}$ thermal UAV images acquired around noon (solar time), the pixels of which were significantly linked to midday water potential (MWP) measurements. UAV equipped with lidar sensors also enabled the detection of rows, the 3D reconstruction of a vine plantation (Llorens et al., 2011) and the quantifying of vineyard canopy (Llorens et al., 2011; Matthews and Jensen, 2012), while airborne lidar images enabled the mapping of landscape linear features (ditches) in a viticultural catchment (Bailly et al., 2008, 2011) and also the hydro-geomorphological analysis of terraced vineyards (Tarolli et al., 2015). UAVs equipped with a visible camera and taking multiangular images using the computer vision technique of structure from motion also enabled the 3-D reconstruction of a vine plantation and were promising in LAI estimation (Matthews and Jensen, 2013).

UAVs allow for the acquisition of spectral or thermal measurements that are very comparable to proxy measurements and are generally carried out along with field proxy measurements. Their use, however, requires a perfect mastering of a chain consisting of image series acquisition, acute georeferencing, spectral calibration, mosaicking and processing, which is the subject of ongoing technical developments, as shown by Verger et al. (2014) for predicting the green area index of annual crops.

\subsection{Proxy measurements of terroir and their statistical processing}

\subsubsection{Geophysical proxy measurements}

Observations should account for the entire depth of the root systems of vines, which may explore the soil parental material, often being a surficial formation (Vaudour, 2002, 2003; Costantini et al., 2012). Geophysical techniques applied to soil (Samouëlian et al., 2005; Doolittle and Brevik, 2014) offer a unique opportunity to explore deep horizons, and it may be expected that key soil properties related to the soil-vine water balance be retrieved from EMI or ground-penetrating radar (GPR) measurements, in possible conjunction with remote-sensing images. However, as in the case of remotesensing images, these techniques require local calibration as the measured signal is a bulk signal. Sensing results are often limited to qualitative information and geophysical sensing results are ambiguous, making reliable quantification of sensing information still a major challenge (Werban et al., 2013).

Indeed, geophysical surveys have mainly resulted in delineating within-field zones (Lamb et al., 2005; Taylor et al., 2009; Costantini et al., 2010; André et al., 2012; Mar- tini et al., 2013; Priori et al., 2013a, b), rather than predicting soil properties, such as clay content (Rodríguez-Pérez et al., 2011; Andrenelli et al., 2013), extractable $\mathrm{Na}^{+}$and $\mathrm{Mg}^{2+}$ contents (Rodríguez-Pérez et al., 2011), or soil moisture (Brillante et al., 2014). Apparent electrical conductivity $(\mathrm{ECa})$ values are "affected by various soil properties in a complex manner and it is difficult to discriminate the weight that each soil parameter has on the final apparent measured ECa" (Martini et al., 2013) so that the Pearson's correlation coefficient is often not significantly high between ECa and soil parameters such as clay content or gravimetric water content. However, Brillante et al. (2014) state that, when soil characteristics are available, it is possible to take them into account in a multiple adaptive regression spline model to build a pedotransfer function for predicting soil moisture from ECa with reduced error ( $\pm 2 \%$ vol.).

\subsubsection{Canopy and grape proxy measurements}

In addition to field reflectance measurements on leaves to define spectral indices of water status (e.g. Rodríguez-Pérez et al., 2007), several field sensors have been developed in the last decade not only for characterizing canopy and vigour - for instance, with Crop Circle ${ }^{\circledR}$ passive reflectance sensors and active sensors (e.g. Stamatiadis et al., 2010) and Greenseeker ${ }^{\circledR}$ reflectance sensors computing NDVI values in real time (e.g. Mazetto et al., 2010) or ground-based lidar scanner for LAI estimation (Arnó et al., 2013) - but also for measuring grape quality parameters including using the Multiplex ${ }^{\circledR}$ portable sensor (Ben Ghozlen et al., 2010; Bramley et al., 2011b; Baluja et al., 2012; Agati et al., 2013). In particular, both fluorescence-based anthocyanin and flavonol indices originating from this sensor showed a high potential for monitoring technological maturity, according to the recent findings by Agati et al. (2013), in Sangiovese and Vermentino varieties respectively.

\subsubsection{The issue of big-data handling and the statistical processing of the varied spatial data collected}

In addition to remote and proxy data collected from distinct sensors, the use of mobile devices with multitag technologies (Cunha et al., 2010; Luvisi et al., 2011) facilitates the recording of a great wealth of data. These numerous spatial data have stimulated new developments in both software and hardware, jointly with statistical processing which stems from geostatistics, image pattern recognition and satellite image processing and which includes machine learning. However, the most common pattern adopted for within-field spatial data and observed for $\sim 40$ of the studies in terroirrelated research carried out in the last decade (Table 3) relied on geostatistical analysis, as emphasized by Baveye and Laba (2015). Considering the target parameter as a random property following a random process with an assumption of stationarity (i.e. there is the same degree of variation from 
Table 3. Use of geostatistics in the zoning studies carried out over the 2002-2013 period (see Fig. 2).

\begin{tabular}{lc}
\hline Use of geostatistics & $N$ \\
\hline No geostatistics & 87 \\
Ordinary kriging & 15 \\
Geostatistics but unexplained & 8 \\
Block kriging & 6 \\
Further use of variogram attributes & 5 \\
Factorial, co-kriging, block co-kriging & 2 \\
\hline
\end{tabular}

Legend: $N$ - number of papers

place to place), Matheron $(1962,1965)$ formalized the approach to predict target properties from spatially correlated sample data through the computation of the semi-empirical variogram, to which are fitted a number of standard parametric models (Oliver and Webster, 2014). "Kriging is a generic term for a range of least-squares methods to provide the best linear unbiased predictions in the sense of minimum variance", through solving a set of linear equations (the kriging system) from the fitted variogram function and the available data (Oliver and Webster, 2014). Ordinary kriging based on primary spatial information such as yield or ECa is the most popular method used in terroir-related studies (Table 3), though more sophisticated spatial models using ancillary spatial information have also been built, such as block co-kriging with a hyperspectral image (Lagacherie et al., 2012) or factorial kriging of several soil variables and ECa (Morari et al., 2009). To single out NTU-based viticultural terroir units on the province scale $(1: 125000$ scale), Priori et al. (2014) combined a multivariate and geostatistical approach showing the variability of the soilscapes within the DOC and DOCG territories in Italy. A first principal component analysis (PCA) was performed to relate climate, pedoclimate and morphometric features to the viticultural data, and a second PCA linked the main soil features with viticultural data. The two PCAs revealed which environmental features were better related to the viticultural parameters of the experimental farms. Several geostatistical models (Castrignanò et al., 2009) were then used to spatialize the selected environmental features: (i) regression kriging to interpolate rooting depth; (ii) simple kriging with varying local means, to interpolate coarse fragments and redoximorphic mottle depth; and (iii) multicollocated simple co-kriging with a varying local mean to interpolate AWC, clay and sand content. Finally, a $k$-means cluster analysis was performed in the viticultural areas, using the selected variable maps (mean annual temperature, mean annual precipitation, mean annual soil temperature, elevation, clay, sand, coarse fragment content, available water capacity, rooting and redoximorphic mottle depths) to determine the NTU-based viticultural terroir units.

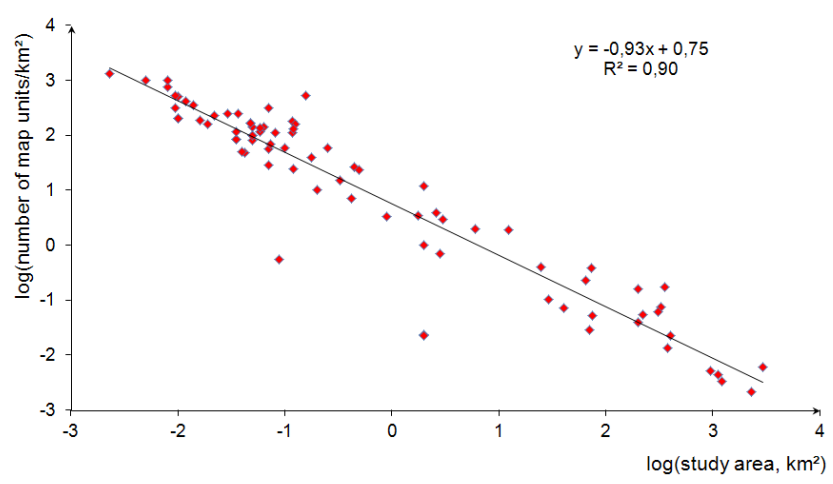

Figure 5. Relationship between the number of map units vs. the study area (log-transformed variables). 2002-early 2014 period (see Fig. 2).

The map results obtained from digital terroir zoning performed at regional scales over some thousands of square kilometres lead to the need for a better understanding of the issue of the relevant scales for defining and managing terroirs. It is important to address the usefulness of both spatial and temporal resolutions that provide insights into terroir zoning according to the aim of the research or management practice. Studies need to examine the nature of within-field zones and the regional terroir units as the relationship between the number of map units and the surveyed area is log-linear (Fig. 5).

The underlying motivations for detailed assessments of the within-field spatial variation of yield, biomass and soil properties are related to the variable-rate application of inputs and selective harvesting at parcel level (Arnó et al., 2012; Unamunzaga et al., 2014). However, considering the withinfield scale only may be questionable in the case of highly parcelled vineyards of less than 1 ha each, such as in European countries with secular viticulture. More than ever, the issue of information synthesis and spatial scale is at the very heart of the spatial modelling of terroir (Vaudour, 2002). Considering a whole 90 ha vineyard composed of 27 contiguous fields, Santesteban et al. (2013) showed that a per-field, within-field study would have resulted in missing the spatial trend due to slope. Therefore, the usefulness of the multiplefield approach becomes one of a "whole-vineyard" or regional approach. Such issues similarly arise when attempting to predict the vine water status from a set of leaf and stem predawn water potential (PLWP/SWP) or midday (MWP) measurements, which are very time-consuming, require accurate methods to collect with a pressure chamber (Scholander et al., 1965) and should be made at several fields managed by the vineyard operation. Using PLWP (Acevedo-Opazo et al., 2008a, b, 2010b) or MWP (Acevedo-Opazo et al., 2010a, 2013) measurements, Acevedo-Opazo et al. (2008a, b, 2010a, b, 2013) devised a linear model applicable at the within-field level but requiring a time-consuming calibration set; in the case of PLWP, it corresponded to rainfed vineyards with high water stress, while in the case of MWP, it 
was aimed at scheduling irrigation. A similar approach using $\delta^{13} \mathrm{C}$ measurements as ancillary variables enabled the extrapolation of stem water potentials for a rainfed vineyard with moderate water stress (Herrero-Langreo et al., 2013). These approaches may be transferable to a whole-vineyard scale $\left(\sim 29 \mathrm{~km}^{2}\right)$, according to Baralon et al. (2012), who constructed an important measurement database (58 fields monitored in all) over the course of three consecutive vintages. This approach considered a stratified sampling based on soil types, which is most effective when water restriction is high (Taylor et al., 2010). However, several limitations hinder its practical application, namely those due to spatial sampling optimization and the improvement of the temporal resolution of the model, using real-time monitoring sensors (such as sap flow sensors) (Herrero-Langreo et al., 2013). According to farmers, a model should be capable of predicting water stress at least 2 weeks before severe irreversible water stress damage occurs (J. C. Viaud, personal communication, 2014).

Arnó et al. (2012) stated that overall within-field variability of grape yield and quality raises important questions concerning whether site-specific crop management could be used in vineyards. Problems arise, in particular, when looking for causes of this variability, especially those related to the presence of soil carbonates, which may lead to Mn deficiencies, with deleterious effects on grape colour. Another problem pointed out by Baveye and Laba (2015) and related to $\mathrm{N}$ or $\mathrm{P}$ manuring is the frequent possibility that $\mathrm{P}$ or $\mathrm{N}$ deficiency in a management zone may be due to a higher leaching rate in the area, leading to an increased rather than decreased risk of groundwater contamination if more fertilizer is applied in this management zone.

\subsection{Modelling and depicting climate on the region-to-vineyard scale}

Another growth area in terroir zoning studies is the development of spatial climate-data products. Historically, a region's climate and suitability for viticulture were assessed via climate station analyses, which seldom depict the spatial variation of climate at actual or prospective vineyard sites within wine-producing regions (Jones et al., 2010). As a result, reference vineyard networks were developed within regions to better capture the spatial climate characteristics (e.g. Jones and Davis, 2000). However, the low network density even in reference vineyard networks does not account for the range in mesoclimates found within regions. To overcome these issues, spatial climate-data products providing robust, validated and more spatially appropriate climate data have been developed through the interpolation of existing longterm, quality-controlled data sources. Numerous techniques, such as kriging and smoothing splines, have been used to produce interpolated surfaces from hundreds to thousands of stations containing valuable meteorological inputs. The results are spatial climate products on daily or monthly timescales and on a range of spatial and temporal scales such as Daymet
(Thornton et al., 1997), PRISM (Parameter-elevation Relationships on Independent Slopes Model) (Daly et al., 2008) and WorldClim (Hijmans et al., 2005). Most of these approaches use elevation data (digital elevation data) and station climate data to calculate a climate-elevation regression for each grid cell, and stations entering the regression are assigned weights based primarily on the physiographic similarity of the station to the grid cell (Daly et al., 2008). These models attempt to account for location, elevation, coastal proximity, aspect, vertical differences in atmospheric layers and orographic effects, although they can vary in the number and complexity of the factors involved. Validation procedures have shown that these products are generally robust on the scales for which they have been developed (Daly et al., 2008) and even at sub-grid resolutions, showing accuracy in regions characterized by sparse station data coverage, large elevation gradients, rain shadows, inversions, cold air drainage and coastal effects.

Using these new gridded climate-data sets, previous studies have examined viticulture region climate characteristics at various resolutions, including in 18 wine regions in $\mathrm{Eu}-$ rope ( $1 \mathrm{~km}$; Jones et al., 2009), 50 PDOs and sub-PDOs in Portugal (1 km; Jones and Alves, 2012), 35 PGIs and PDOs in Greece (1 km; Anderson et al., 2014), 135 American Viticultural Areas in the western United States ( $400 \mathrm{~m}$; Jones et al., 2010), 63 Geographical Indications in Australia (500 m; Hall and Jones, 2010) and 21 wine regions in New Zealand (500 m; Anderson et al., 2012) and providing more holistic measures to help understand the range of climates within viticulture regions. Various climate parameters such as heat accumulation indices, frost timing, evapotranspiration and dryness indices are often used along with mapping and spatial summaries over delimited winegrowing regions, ultimately helping to define the climate component of terroir over time and space.

Much work has been done examining the likely impacts of climate change on water and/or nitrogen dynamics through models, such as Lebon's (adapted from the models in Riou et al. 1989, 1994; Lebon et al., 2003) Lin and Host's (Costantini et al., 2009), Soil and Water Assessment Tool (SWAT) (Martínez-Casasnovas et al., 2013; Ramos and MartínezCasasnovas, 2014) and soil-water-atmosphere-plant model (SWAP) (Bonfante et al., 2011) hydropedological models that aim to simulate the dynamics in seasonal soil water balance. Kersebaum's model was proposed to simulate nitrogen dynamics (Nendel and Kersebaum, 2004), while the Simulateur mulTIdisciplinaire pour les Cultures Standard (STICS) model simulates crop growth, soil water and nitrogen balances driven by daily climatic data (Brisson et al., 2009); the Water baLance for Intercropped Systems (WaLIS) model simulates water partitioning in intercropped vineyards (Celette et al., 2010). WaLIS was also used to quantify the effects of water deficit and nitrogen stress on yield components (Guilpart et al., 2014). To model the seasonal pattern of evaporation from a grassed Mediterranean vineyard, Montes 
et al. (2014) recently devised a soil-vegetation-atmospheretransfer (SVAT) model coupling an evaporation formulation together with a reservoir-type soil water balance model. Attempts have also been made to use micromorphology to characterize and monitor soil internal drainage of vineyards and olive tree groves (Costantini et al., 2006). Bonfante et al. (2011) have integrated the outputs of the SWAP model with a set of regional spatial data in order to map crop water stress indices together with soil map units, bioclimatic indices and potential radiation onto terroirs with simulated crop water status. However, scale issues need to be further addressed for both terroir zoning and other applications, such as the mapping of water stress. In vineyards, micro-variations in weather and climate often produce the greatest risk (e.g. frost or freeze zones, heat stress areas), and to truly address climate change we will need finer scales to assess the potential impacts (Quénol and Bonnardot, 2014).

\section{Outlook: terroir sustainability assessment and the design of new preservation practices}

The above-mentioned modelling approaches of terroir or terroir components with the aim of both spatially and temporally updating information lead to certain considerations in an emerging and complex study area: the sustainability assessment of terroirs. Some recent zoning studies using geospatial technologies have addressed this issue in terms of erosion (Table 2). Terroir sustainability started to be accounted for in the late 1990s, through some growers unions' initiatives in both California and Champagne and also through the growing awareness of soil contamination by copper due to the cumulated use of Bordeaux mixture (Vaudour, 2003). Mediterranean viticultural areas are amongst those most exposed and aware of the sustainability issue because of the soil losses due to intense erosional processes (e.g. Le Bissonnais et al., 2007; Martínez-Casasnovas et al., 2009, 2013; Novara et al., 2011), which may lead to the destruction of a vineyard field (Fig. 6). Another issue is that of abandonment and land use change due to either urban pressure, aging of farmers or declines in profitability (Fig. 7).

Depletion of soil fertility in general, along with the concomitant problems of weeds, pests and diseases, is the fundamental root cause of low agricultural production on a global level (Tan et al., 2005). Even if grapevines are not demanding with regard to nutrients, they nevertheless require an adequate supply, which may no longer exist in terroirs where the soils are undergoing degradation processes, especially soil losses (Le Bissonnais et al., 2007; MartínezCasasnovas et al., 2009, 2013; Paroissien et al., 2010; Novara et al., 2011; Quiquerez et al., 2014; Chevigny et al., 2014; Lieskovsky and Kenderessy, 2014), nutrient depletion (Ramos and Martínez-Casanovas, 2006), compaction (Lagacherie et al., 2006), salinization and sodization (Clark et al., 2002; Crescimanno and Garofalo, 2006; Crescimanno et

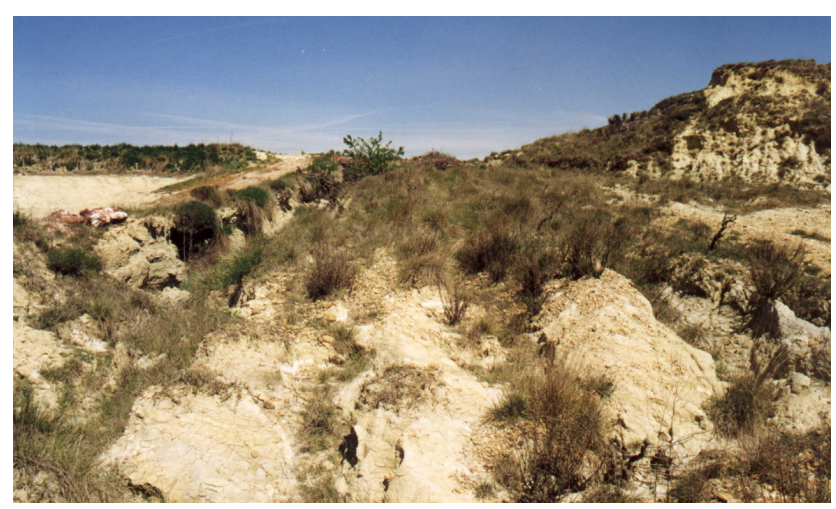

Figure 6. Former vineyard field destroyed by erosion in the low Southern Rhône Valley, with dead vines still visible (Photograph by E. Vaudour).

al., 2007; Costantini and Lorenzetti, 2013), pesticide runoff and deposition (Landry et al., 2005; Louchart and Voltz, 2007; Lacas et al., 2012; Daouk et al., 2013; Lefrancq et al., 2013) and copper contamination (Pieztrak and McPhail, 2004; Chopin et al., 2008; Komárek et al., 2008; Wightwick et al., 2008; Mirlean et al., 2007, 2009; Rusjan et al., 2007; El Hadri et al., 2012; Fernández-Calviño et al., 2013; El Azzi et al., 2013; Lai et al., 2013). In Burgundy, using vine-stock unearthing-burying measurements (Brenot et al., 2008), Chevigny et al. (2014) estimated that the erosion rate had increased significantly over the last decade and also that the spatial distribution of erosion had changed and was now basically controlled by slope steepness and present-day vineyard chemical weeding and no-tillage management instead of past surface tillage. Using the same method in Languedoc, Paroissien et al. (2010) estimated that the average soil loss reached $10.5 \mathrm{tha}^{-1}$ year $^{-1}$ and was much higher than the average erosion rates established around $3 \mathrm{tha}^{-1}$ year $^{-1}$ for the other cultivated soils. The high vulnerability of vineyard soil to erosion may be partly explained by the steep slopes where vineyards are established, but also by the generally low content in organic matter $(<2 \%)$ and the low microbial activity of soils, which leads to a reduced aggregate stability that increases soil crusting and soil erosion (Le Bissonnais et al., 2007). Very poor eroded soils can show low or very low nitrogen content, as a consequence of little soil organic matter. In the Pénédes viticultural region, Ramos and MartínezCasanovas (2006) estimated that runoff processes exported significant amounts of nutrients, which represented as much as $8 \mathrm{~kg} \mathrm{ha}^{-1}$ year $^{-1}$ of $\mathrm{N}$ and $6.5 \mathrm{~kg} \mathrm{ha}^{-1}$ year $^{-1}$ of P. Moreover, the nitrogen deficiency can be enhanced in moderate to severe water stress conditions (Costantini et al., 2013). According to Blavet et al. (2009), chemically weeded vineyards result in the highest runoff rates and soil losses, but the losses can be reduced when the prunings are left on the soil, when straw mulching is used, when rock fragments are left, and when grass intercrops are used. The corollary issue of runoff 


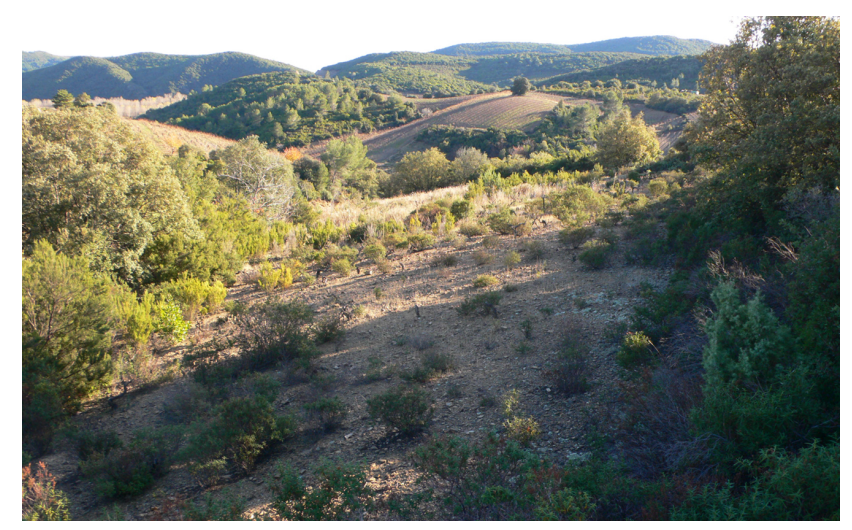

Figure 7. Abandoned vineyard field colonized by native Mediterranean plant species in the Languedoc region (France), with some vines still visible (Photograph by E. Vaudour).

is that, in addition to soil erosion and soil nutrient loss, it also leads to fertilizer and pesticide residue loss to surface waters, depending on the timing of the applied pesticide (Louchart and Voltz, 2007).

In order to mitigate environmental damages and foster soil conservation and restoration, studies over the past decade have focused on the specific effect of one or several soil surface management techniques, such as cover cropping vs chemical weeding or tillage and/or mulching, on soil structural stability (Goulet et al., 2004; Ruiz-Colmenero et al., 2011, 2013), soil loss (Ruiz-Colmenero et al., 2011, 2013; Novara et al., 2011; Lieskovsky and Kenderessy, 2014), pesticide leaching (Landry et al., 2005), soil nutrient and water management, vine growth and yield (Steenwerth and Belina, 2008, 2010; Ripoche et al., 2010, 2011; Novara et al., 2013), soil C dynamics (Steenwerth et al., 2010; Agnelli et al., 2014), and grape quality (Lee and Steenwerth, 2013). As recently described by Ruiz-Colmenero et al. (2013) and Agnelli et al. (2014), a greater organic-matter accumulation is fostered by the presence of the grass cover and the absence of tillage. In the Vosne-Romanée area in Burgundy, Landry et al. (2005) showed that glyphosate and its metabolite (AMPA) leached in greater amounts through a chemically treated bare Calcosol than through a vegetated Calcosol. In an upslope vineyard in the Beaujolais area, Lacas et al. (2012) demonstrated the usefulness of a grass buffer strip on a coarsely textured soil to limit the dispersal of diuron losses by runoff towards surface and subsurface water. Jacobson et al. (2005) studied the leaching of the herbicide diuron jointly with that of copper, through vineyard soils contaminated with copper, and found no direct interaction between the metal and herbicide but interpreted their findings as meaning that $\mathrm{Cu}$ was possibly affecting microbial activity, resulting in slight increases in diuron persistence.

Despite the varied environmental problems that viticultural terroirs are facing currently, putting their functioning at risk, the design of new preservation and mitigation practices has just begun to be addressed in the literature of the past decade. Although some methods to globally assess the sustainability of agricultural systems have emerged (Bockstaller et al., 2009), they have seldom addressed the sustainability of the viticultural system (Abbona et al., 2007), not only from the environmental point of view but also with regard to the attractiveness of the landscape, which, in many viticultural areas, adds considerable value to the wine produced and the region in question (Tempesta et al., 2010; Costantini and Barbetti, 2008).

The global water crisis, particularly water scarcity (Hanjra and Qureshi, 2010), that threatens those viticultural areas under semi-arid or arid climates, particularly in the Mediterranean area (Iglesias et al., 2007; Plan Bleu, 2013), questions the relevancy of irrigating, in addition to the degradative effects that this practise may have on soil properties over a long-term period and its high remediation costs (Hajkowitcz and Young, 2005). To address the issue of terroir sustainability in the years to come, one of the greatest challenges is the design of efficient soil restoration practices along with crop and/or intercrop management plans, taking into account the possible effects of climate change. This implies a complex multicriteria decision analysis, as attempted by Ripoche et al. (2010), in order to evaluate a range of intercrop management plans. The monitoring of soil quality as potentially obtainable from remote or proxy techniques is likely to identify when soil degradation is occurring and to allow management intervention. Amongst the key biological indicators are soil organic carbon, potentially mineralisable nitrogen and microbial biomass (Riches et al., 2013; Salome et al., 2014; Zornoza et al., 2015), although further research is still needed to identify a suite of biological indicators for viticultural soils. The application of organic amendments is likely to improve soil quality, but its effects are seldom studied, particularly during long-term experiments (Tatti et al., 2012). In rainfed Marchesi Antinori vineyards observed over two consecutive growing seasons, Baronti et al. (2014) suggested that biochar amendment could be used to improve soil water content, but other possible negative effects of changes in surface albedo or the accumulation of polycyclic aromatic hydrocarbons still need to be studied. In contrast, considering a 3-year period in a Valais vineyard (Switzerland), Schmidt et al. (2014) observed only small and mostly non-significant effects of either biochar or biochar-compost amendments. However, over the same duration in a vineyard in Jumilla (Spain), other organic inputs, such as winery and distillery waste composts, induced "an increase in the activity of the soil microorganisms and in the soil macro and micronutrient contents, as well as a slow release of inorganic N" (Bustamante et al., 2011) in a soil characterized by a highly calcareous sandy loam (Torriorthent). When soils are biologically very poor, even organic farming may be not enough to restore soil functionality, at least over a short time period (Costantini et al., 2014). Coll et al. (2011) evaluated the longterm effect of organic viticulture on soil quality in commer- 
cial vineyards of Languedoc, where plots which had been organically managed for 7,11 and 17 years where compared to conventionally managed plots. The results emphasized that a transition period of 7-11 years, depending on the considered indicator, was needed to clearly separate conventional and organic farming. The overall benefits of organic farming were an increase in soil organic matter, potassium content, soil microbial biomass, plant feeding, fungal feeding and nematode densities, while its drawbacks were increased soil compaction and decreased endogeic earthworm density (due to reduced soil porosity), both consequences of the increase in the traffic for tillage and phytosanitary treatments in organic management. The grapevines studied by these authors were not intercropped with grass, and knowledge is actually scarce about the joint long-term environmental effects of the various possible sets of practices, such as cover or intercrop, mulching, mouldboard ploughing and/or tillage depth and frequency, type and quantity of applied organic amendments, and the use of chemical fertilizer.

Further studies should also address the possible reintroduction of agroforestry systems jointly with vineyards, as traditionally practised in Mediterranean regions, such as in Ancient Greece (Vaudour and Boulay, 2013) or in Italy and Provence till the 19th century. Such systems are known to limit water consumption, fertilizers and pest diseases, particularly Botrytis cinerea bunch rot in Portugal (Altieri and Nicholls, 2002), and have positive impacts on phytoseid mite species, known for their ability to control mite pests, as shown in the last decade for vines co-planted with Sorbus domestica L. or Pinus pinea L. in Languedoc (Liguori et al., 2011).

\section{Conclusions}

Recent studies based either on metabolomics or on the $\mathrm{Sr}$ isotopic ratio lead to a strengthening of the assumption that geographical origin does leave a footprint in wines and that both soil and substrate, in interaction with climate and cultural choices, influence the shaping of grapevine phenology and grape and wine quality. Furthermore, the use of the current "omics" technologies seems to confirm the existence of a "microbial terroir" as a key factor in regional variation among wine grapes. Despite the role of soil microbial communities on terroir still being unclear, in the near future the combination of the omics techniques and traditional approaches could give further insights into activity and composition of vine-associated microbes, especially those living on the grape or leaf surface (phyllosphere) and root surfaces (rhizosphere) but also those within the plant tissues (endophytes), and their interactions with the plant and soil.

The differentiation and mapping of viticultural terroirs, in the sense of homogeneous regions of grape and wine quality, need comprehensive spatial modelling of soil, agronomical and climatic properties, including their changes through time. Because of this, a myriad of either remote- or proxysensing techniques develop, along with the corollary challenge of processing large quantities of data acquired at a very fine spatial resolution and/or at several spatial resolutions, scales and organizational levels. These techniques in data collection and processing are needed to produce easy-toupdate decision maps with associated uncertainties that allow users to make appropriate and timely management decisions. This is a revolution in the spatial management of terroir units, as the managed zones will be updatable and the effects of viticultural and/or soil management practices might be easier to control. The prospect of facilitated terroir spatial monitoring makes it possible to address another great challenge in the years to come: the issue of terroir sustainability and the construction of efficient strategies for assessing and applying adequate viticultural and/or soil practices across numerous scales. These include the design of efficient soil restoration practices along with crop and/or intercrop management plans and/or agroforestry viticultural systems that take into account the possible effects of climate change. Therefore, terroirs are more and more likely to be considered as part of the concept of ecosystem services, as viticultural agro-ecosystems, the services of which need to be constantly evaluated and rationalized.

Acknowledgements. The authors wish to thank the anonymous referees for their constructive comments.

Edited by: A. Cerdà

\section{References}

Abbona, E. A., Sarandón, S. J., Marasas, M. E., and Astier, M.: Ecological sustainability evaluation of traditional management in different systems in Berisso, Argentina, Agr. Ecosyst. Environ., 119, 335-345, 2007.

Acevedo-Opazo, C., Tisseyre, B., Guillaume, S., and Ojeda, H.: The potential of high spatial resolution information to define withinvineyard zones related to vine water status, Precis. Agric., 9, 285-302, 2008a.

Acevedo-Opazo, C., Tisseyre, B., Ojeda, H., Ortega-Farias, S., and Guillaume, S.: Is it possible to assess the spatial variability of vine water status? J. Int. Sci. Vigne Vin, 42, 203-219, 2008b.

Acevedo-Opazo, C., Ortega-Farias, S., and Fuentes, S.: Effects of grapevine (Vitis vinifera L.) water status on water consumption, vegetative growth and grape quality: an irrigation scheduling application to achieve regulated deficit irrigation, Agr. Water Manage., 97, 956-964, 2010a.

Acevedo-Opazo, C., Tisseyre, B., Ojeda, H., and Guillaume, S.: Spatial extrapolation of the vine (Vitis vinifera L.) water status: a first step towards a spatial prediction model, Irrigation Sci., 28, 143-155, 2010b.

Acevedo-Opazo, C., Valdés-Gómez, H., Taylor, J. A., Avalo, A., Verdugo-Vásquez, N., Araya, M., Jara-Rojas, F., and Tisseyre, B.: Assessment of an empirical spatial prediction model of vine 
water status for irrigation management in a grapevine field, Agr. Water Manage., 124, 58-68, 2013.

Agati, G., D’Onofrio, C., Ducci, E., Cuzzola, A., Remorini, D., Tuccio, L., Lazzini, F., and Mattii, G.: Potential of a multiparametric optical sensor for determining in situ the maturity components of red and white Vitis vinifera wine grapes, J. Agr. Food Chem., 61, 12211-12218, 2013.

Agnelli, A., Bol, R., Trumbore, S. E., Dixon, L., Cocco, S., and Corti, G.: Carbon and nitrogen in soil and vine roots in harrowed and grass-covered vineyards, Agr. Ecosyst. Environ., 193, 70-82, 2014.

Altieri, M. A. and Nicholls, C. I.: The simplification of traditional vineyard based agroforests in northwestern Portugal: some ecological implications, Agroforest. Syst., 56, 185-191, 2002.

Anastasiadi, M., Zira, A., Magiatis, P., Haroutounian, S. A., Skaltsounis, A. L., and Mikros, E.: 1H NMR-based metabonomics for the classification of Greek wines according to variety, region, and vintage. Comparison with HPLC data, J. Agr. Food Chem., 57, 11067-11074, 2009.

Anderson, J. D., Jones, G. V., Tait, A., Hall, A., and Trought, M. T. C.: Analysis of viticulture region climate structure and suitability in New Zealand, International Journal of Vine and Wine Sciences, 46, 149-165, 2012.

Anderson, J. D., Dimou, P., Jones, G. V., Kalivas, D., Koufos, G., Mavromatis, T., Koundouras, S., and Fyllas, N. M.: Harvest dates, climate, and viticultural region zoning in Greece. Proceedings of the 10th International Terroir Congress, 7-10 July, 2014, Tokaj, Hungary, 2, 55-60, 2014.

André, F., Van Leeuwen, Saussez, S., Van Durmen, R., Bogaert, P., Moghadas, D., de Rességuier, L., Delvaux, B., Vereecken, H., and Lambot, S.: High resolution imaging of a vineyard in south of France using ground-penetrating radar, electromagnetic induction and electrical resistivity tomography, J. Appl. Geophys., 78, 113-122, 2012.

Andrenelli, M. C., Magini, S., Pellegrini, S., Perria, R., Vignozzi, N., and Costantini, E. A. C.: The use of the ARP ${ }^{\circledR}$ system to reduce the costs of soil survey for precision viticulture, J. Appl. Geophys., 99, 24-34, 2013.

Arnó, J., Martínez-Casasnovas, J. A., Ribes-Dasi, M., and Rosell, J. R.: Review. Precision viticulture. Research topics, challenges and opportunities in site-specific vineyard management, Spanish J. Agr. Res., 7, 779-790, 2009.

Arnó, J., Rosell, J. R., Blanco, R., Ramos, M. C., and MartínezCasasnovas, J. A.: Spatial variability in grape yield and quality influenced by crop and soil nutrition characteristics, Precis. Agric., 13, 393-410, 2012.

Arnó, J., Escolà, A., Vallès, J. M., Llorens, J., Sanz, R., Masip, J., Palacín, J., and Rosell-Polo, J. R.: Leaf area index estimation in vineyards using a ground-based LiDAR scanner, Precis. Agric., 14, 290-306, 2013.

Bailly, J. S., Lagacherie, P., Millier, C., Puech, C., and Kosuth, P.: Agrarian landscapes linear features detection from LiDAR: application to artificial drainage networks, Int. J. Remote Sens., 29, 3489-3508, 2008.

Bailly, J. S., Levavasseur, F., and Lagacherie, P.: A spatial stochastic algorithm to reconstruct artificial drainage networks from incomplete network delineations, Int. J. Appl. Earth Obs., 13, 853-862, 2011.
Baluja, J., Diago, M. P., Balda, P., Zorer, R., Meggio, F., Morales, F., and Tardaguila, J.: Assessment of vineyard water status variability by thermal and multispectral imagery using an unmanned aerial vehicle (UAV), Irrigation Sci., 30, 511-522, 2012a.

Baluja, J., Diago, M. P., Goovaerts, P., and Tardaguila, J.: Assessment of the spatial variability of anthocyanins in grapes using a fluorescence sensor: relationships with vine vigour and yield, Precis. Agric., 13, 457-472, 2012b.

Baluja, J., Tardaguila, J., Ayestaran, B., and Diago, M. P.: Spatial variability of grape composition in a Tempranillo (Vitis vinifera L.) vineyard over a 3-year survey, Precis. Agric., 14, 40-58, 2013.

Baralon, K., Payan, J. C., Salançon, E., and Tisseyre, B.: SPIDER: spatial extrapolation of the vine water status at the whole denomination scale from a reference site, J. Int. Sci. Vigne Vin, 46, 167-175, 2012.

Barata, A., Malfeito-Ferreira, M., and Loureiro, V.: The microbial ecology of wine grape berries, Int. J. Food Microbiol., 153, 243259, 2012.

Barham, E.: Translating terroir: the global challenge of French AOC labelling, J. Rural Stud., 19, 127-138, 2003.

Baronti, S., Vaccari, F. P., Miglietta, F., Calzolari, C., Lugato, E., Orlandini, S., Pini, R., Zulian, C., and Genesio, L.: Impact of biochar application on plant water relations in Vitis vinifera (L.), Eur. J. Agron., 53, 38-44, 2014.

Baveye, P. C. and Laba, M.: Moving away from the geostatistical lamppost: why, where, and how does the spatial heterogeneity of soils matter?, Ecol. Model., 298, 24-38, 2015.

Ben Ghozlen, N., Cerovic, Z. G., Germain, C., Toutain, S., and Latouche, G.: Non-destructive optical monitoring of grape maturation by proximal sensing, Sensors, 10, 10040-10068, 2010.

Bellvert, J., Zarco-Tejada, P. J., Girona, J., and Fereres, E.: Mapping crop water stress index in a "Pinot-noir" vineyard: comparing ground measurements with thermal remote sensing imagery from an unmanned aerial vehicle, Precis. Agric., 15, 361-376, 2014.

Besky, S.: The labor of terroir and the terroir of labor: Geographical Indication and Darjeeling tea plantations, Agric. Human Values, 31, 83-96, 2014.

Beucher, S. and Lantuéjoul, C.: Use of watersheds in contour detection, International Workshop on image processing, Real time edge and motion detection/estimation, Rennes, France, 1721 September 1979, available at: http://cmm.ensmp.fr/ beucher/ publi/watershed.pdf (last access: 13 March 2015), 1979.

Blavet, D., De Noni, G., Le Bissonnais, Y., Léonard, M., Maillo, L., Laurent, J. Y., Asseline, J., Leprun, J. C., Arshad, M. A., and Roose, E.: Effect of land use and management on the early stages of soil water erosion in French Mediterranean vineyards, Soil Till. Res., 106, 124-136, 2009.

Bockstaller, C., Guichard, L., Keichinger, O., Girardin, P., Galan, M. B., and Gaillard, G.: Comparison of methods to assess the sustainability of agricultural systems. A review, Agron. Sustain. Dev., 29, 223-235, 2009.

Bokulich, N. A., Thorngate, J. H., Richardson, P. M., and Mills, D. A.: Microbial biogeography of wine grapes is conditioned by cultivar, vintage and climate, P. Natl. Acad. Sci., 111, E139-E148, 2013.

Bonfante, A., Basile, A., Langella, G., Manna, P., and Terribile, F.: A physically oriented approach to analysis and mapping of terroirs, Geoderma, 167-168, 103-117, 2011. 
Bowen, S. and Zapata, A. V.: Geographical indications, terroir, and socioeconomic and ecological sustainability: the case of tequila, J. Rural Stud., 25, 108-119, 2009.

Bramley, R. G. V.: Understanding variability in winegrape production systems. 2. Within vineyard variation in quality overall several vintages, Aust. J. Grape Wine R., 11, 33-42, 2005.

Bramley, R. G. V. and Hamilton, R. P.: Understanding variability in winegrape production systems. 1. Within vineyard variation in yield overall several vintages, Aust. J. Grape Wine R., 10, 32-45, 2004.

Bramley, R. G. V. and Hamilton, R. P.: Terroir and precision viticulture: are they compatible?, J. Int. Sci. Vigne Vin, 41, 1-8, 2007.

Bramley, R. G. V., Evans, K. J., Dunne, K. J., and Gobbett, D. L.: Spatial variation in response to "reduced input" spray programs for powdery mildew and botrytis identified through whole-ofblock experimentation, Aust. J. Grape Wine R., 17, 341-350, 2011 a.

Bramley, R. G. V., Le Moigne, M., Evain, S., Ouzman, J., Florin, L., Fadaili, E. M., Hinze, C. J., and Cerovic, Z. G.: On-the-go sensing of grape berry anthocyanins during commercial harvest: development and prospects, Aust. J. Grape Wine R., 17, 316326, $2011 b$.

Bramley, R. G. V., Ouzman, J., and Boss, P. K.: Variation in vine vigour, grape yield and vineyard soils and topography as indicators of variation in the chemical composition of grapes, wine and wine sensory attributes, Aust. J. Grape Wine R., 17, 217-229, 2011c.

Bramley, R. G. V., Ouzman, J., and Thornton, C.: Selective harvesting is a feasible and profitable strategy even when grape and wine production is geared towards large fermentation volumes, Aust. J. Grape Wine R., 17, 298-305, 2011 d.

Bramley, R. G. V., Trought, M. C. T., and Praat, J. P.: Vineyard variability in Malborough, New Zealand: characterizing variation in vineyard performance and options for the implementation of precision viticulture, Aust. J. Grape Wine R., 17, 72-78, 2011e.

Brenot, J., Quiquerez, A., Petit, C., and Garcia, J. P.: Erosion rates and sediment budgets in vineyards at 1-m resolution based on stock unearthing (Burgundy, France), Geomorphology, 100, 345-355, 2008.

Brevik, E. C., Cerdà, A., Mataix-Solera, J., Pereg, L., Quinton, J. N., Six, J., and Van Oost, K.: The interdisciplinary nature of SOIL, SOIL, 1, 117-129, doi:10.5194/soil-1-117-2015, 2015.

Brillante, L., Bois, B., Mathieu, O., Bichet, V., Michot, D., and Lévêque, J.: Monitoring soil volume wetness in heterogeneous soils by electrical resistivity. A field-based pedotransfer function, J. Hydrol., 516, 56-66, 2014.

Brisson, N., Launay, M., Mary, B., and Beaudoin, N.: Conceptual basis, formalisations and parameterization of the STICS crop model, Quae, Paris, 2009.

Bulgarelli, D., Schlaeppi, K., Spaepen, S., Ver Loren van Themaat, E., Schulze-Lefert, P.: Structure and functions of the bacterial microbiota of plants, Annu. Rev. Plant Biol., 64, 807-38, 2013.

Bustamante, M. A., Said-Pullicino, D., Agulló, E., Andreu, E., Paredes, C., and Moral, R.: Application of winery and distillery waste composts to a Jumilla (SE Spain) vineyard: Effects on the characteristics of a calcareous sandy-loam soil, Agr. Ecosyst. Environ., 140, 80-87, 2011.

Cabral-Chamorro, A.: Observaciones sobre la regulación y ordenación del mercado del vino en Jerez de la Frontera 1850-1935: antecedentes del consejo regulador de la denominación de origen Jerez-Xérès-Cherry, Agricultura y Sociedad, 44, 171-197, 1987 (in Spanish).

Carey, V. A., Saayman, D., Archer, E., Barbeau, G., and Wallace, M.: Viticultural terroirs in Stellenbosch, South Africa. I. The identification of natural terroir units, J. Int. Sci. Vigne Vin, 42, 169-183, 2008.

Carré, F. and Girard, M. C.: Quantitative mapping of soil types based on regression kriging of taxonomic distances with landform and land cover attributes, Geoderma, 110, 241-263, 2002.

Carré, F. and McBratney, A. B.: Digital terron mapping, Geoderma, 128, 340-353, 2005.

Carré, F., McBratney, A. B., Mayr, T., and Montanarella, L.: Digital soil assessments: beyond DSM, Geoderma, 142, 69-79, 2007.

Castellarin, S. D., Matthews, M. A., Di Gaspero, G., and Gambetta, G. A.: Water deficits accelerate ripening and induce changes in gene expression regulating flavonoid biosynthesis in grape berries, Planta, 227, 101-112, 2007.

Castrignanò, A., Costantini, E. A. C., Barbetti, R., and Sollitto, D.: Accounting for extensive topographic and pedologic secondary information to improve soil mapping, Catena, 77, 28-38, 2009.

Celette, F., Ripoche, A., and Gary, C.: WaLIS. A simple model to simulate water partitioning in a crop association: the example of intercropped vineyard, Agr. Water Manage., 97, 1749-1759, 2010.

Chanussot, J., Bas, P., and Bombrun, L.: Airborne remote sensing of vineyards for the detection of dead vine trees, Geoscience and Remote Sensing Symposium, 2005. IGARSS '05, Proceedings, 2005 IEEE International, 5, 3090-3093, 2005.

Chevigny, E., Quiquerez, A., Petit, C., and Curmi, P.: Lithology, landscape structure and management practice changes: Key factors patterning vineyard soil erosion at metre-scale spatial resolution, Catena, 121, 354-364, 2014.

Chopin, E. I. B., Marin, B., Mkoungafoko, R., Rigaux, A., Hopgood, M. J., Delannoy, E., Cancès, B., and Laurain, M.: Factors affecting distribution and mobility of trace elements $(\mathrm{Cu}, \mathrm{Pb}, \mathrm{Zn})$ in a perennial grapevine (Vitis vinifera L.) in the Champagne region of France, Environ. Pollut., 156, 1092-1098, 2008.

Clark, L. R., Fitzpatrick, R. W., Murray, R. S., and McCarthy, G.: Vineyard soil degradation following irrigation with saline groundwater for twenty years, 17th World Congress of Soil Science Bangkok, Thailand, 14-20, 2002.

Coll, P., Le Cadre, E., Blanchart, E., Hinsinger, P., and Villenave, C.: Organic viticulture and soil quality, a long-term study in Southern France, Appl. Soil Ecol., 50, 37-44, 2011.

Compant, S., Mitter, B., Colli-Mull, J. G., Gangl, H., and Sessitsch, A.: Endophytes of grapevine flowers, berries, and seeds: identification of cultivable bacteria, comparison with other plant parts, and visualization of niches of colonization, Microb. Ecol., 62, 188-197, 2011.

Corbane, C., Andrieux, P., Voltz, M., Chadoeuf, J., Albergel, J., Robbez-Masson, J. M., and Zante, P.: Assessing the variability of soil surface characteristics in row-cropped fields: the case of Mediterranean vineyards in Southern France, Catena, 72, 79-90, 2008a.

Corbane, C., Raclot, D., Jacob, F., Albergel, J., and Andrieux, P.: Remote sensing of soil surface characteristics from a multiscale classification approach, Catena, 75, 308-318, 2008b. 
Corbane, C., Jacob, F., Raclot, D., Albergel, J., and Andrieux, P.: Multitemporal analysis of hydrological soil surface characteristics using aerial photos: A case study on a Mediterranean vineyard, Int. J. Appl. Earth Obs., 18, 356-367, 2012.

Costantini, E. A. C. and Barbetti, R.: Environmental and visual impact analysis of viticulture and olive tree cultivation in the Province of Siena (Italy), Eur. J. Agron., 28, 412-426, 2008.

Costantini, E. A. C. and Bucelli, P.: Soil and terroir, in: Soil security for ecosystem management, edited by: Kapur, S. and Erşahin, S., SpringerBriefs in Environment, Security, Development and Peace, 8, 97-133, doi:10.1007/978-3-319-00699-4_6, 2014.

Costantini, E. A. C. and Lorenzetti, M.: Soil degradation processes in the Italian agricultural and forest ecosystems, Italian J. Agronomy, 8, 233-243, 2013.

Costantini, E. A. C., Pellegrini, S., Vignozzi, N., and Barbetti, R.: Micromorphological characterization and monitoring of internal drainage in soils of vineyards and olive groves in Central Italy, Geoderma, 131, 388-403, 2006.

Costantini, E. A. C., Pellegrini, S., Bucelli, P., Storchi, P., Vignozzi, N., Barbetti, R., and Campagnolo, S.: Relevance of the Lin's and Host hydropedological models to predict grape yield and wine quality, Hydrol. Earth Syst. Sci., 13, 1635-1648, doi:10.5194/hess-13-1635-2009, 2009.

Costantini, E. A. C., Pellegrini, S., Bucelli, P., Barbetti, R., Campagnolo, S., Storchi, P., Magini, S., and Perria, R.: Mapping suitability for Sangiovese wine by means of $\delta^{13} \mathrm{C}$ and geophysical sensors in soils with moderate salinity, Eur. J. Agron., 33, 208217, 2010.

Costantini, E. A. C., Bucelli, P., and Priori, S.: Quaternary landscape history determines the soil functional characters of terroir, Quaternary Int., 265, 63-73, 2012.

Costantini, E. A. C., Agnelli, A., Bucelli, P., Ciambotti, A., Dell'Oro, V., Natarelli, L., Pellegrini, S., Perria, R., Priori, S., Storchi, P., Tsolakis, C., and Vignozzi, N.: Unexpected relationships between $\delta^{13} \mathrm{C}$ and grape performance in organic farming, J. Int. Sci. Vigne Vin, 47, 269-285, 2013.

Costantini, E. A. C., Agnelli, A., Fabiani, A., Gagnarli, E., Mocali, S., Priori, S., Simoni, S., and Valboa, G.: Short term recovery of soil biological functions in a new vineyard cultivated in organic farming, Geophys. Res. Abstr., EGU2014-3691-1, EGU General Assembly 2014, Vienna, Austria, 2014.

Crescimanno, G. and Garofalo, P.: Management of irrigation with saline water in cracking clay soils, Soil Sci. Soc. Am. J., 70, 1774-1787, 2006.

Crescimanno, G., De Santis, A., and Provenzano, G.: Soil structure and bypass flow processes in a Vertisol under sprinkler and drip irrigation, Geoderma, 138, 110-118, 2007.

Cunha, C. R., Peres, E., Morais, R., Oliveira, A. A., Matos, S. G., Fernades, M. G., Ferreira, P. J. S. G., and Reis, M. J. C. S.: The use of mobile devices with multi-tag technologies for an overall contextualized vineyard management, Comput. Electron. Agr., 73, 154-164, 2010.

Da Costa, J. P., Michelet, F., Germain, C., Lavialle, O., and Grenier, G.: Delineation of vine parcels by segmentation of high resolution remote sensed images, Precis. Agric., 8, 95-110, 2007.

Daly, C., Halbleib, M., Smith, J. I., Gibson, W. P., Doggett, M. K., Taylor, G. H., Curtis, J., and Pasteris, P. A.: Physiographicallysensitive mapping of temperature and precipitation across the conterminous United States, Int. J. Climatol., 28, 2031-2064, 2008.

Daniel, R.: The metagenomics of soil, Nat. Rev. Microbiol., 3, 470478, 2005.

Daouk, S., De Alencastro, L. F., and Pfeifer, H. R.: The herbicide glyphosate and its metabolite AMPA in the Lavaux vineyard area, western Switzerland: proof of widespread export to surface waters. Part II: The role of infiltration and surface runoff, J. Environ. Sci. Heal. B, 48, 725-736, doi:10.1080/03601234.2013.780548, 2013.

De Assis Silva, S., Marçal de Queiroz, D., De Assis De Carvalho Pinto, F., and Terra Santos, N.: Characterization and delimitation of the terroir coffee in plantations in the municipal district of Araponga, Minas Gerais, Brazil, Revista Ciência Agronômica, 45, 18-26, 2014.

Delenne, C., Durrieu, S., Rabatel, G., Deshayes, M., Bailly, J. S., Lelong, C., and Couteron, P.: Textural approaches for vineyard detection and characterization using very high spatial resolution remote sensing data, Int. J. Remote Sens., 29, 1153-1167, 2008.

Delenne, C., Durrieu, S., Rabatel, G., and Deshayes, M.: From pixel to vine parcel: a complete methology for vineyard delineation and characterization using remote-sensing data, Comput. Electron. Agr., 70, 78-83, 2010.

Dell'Amico, E., Mazzocchi, M., Cavalca, L., Allievi, L., and Andreoni, V.: Assessment of bacterial community structure in a long-term copper-polluted ex-vineyard soil, Microbiol. Res., 163, 671-683, 2008.

Deloire, A., Vaudour, E., Carey, V., Bonnardot, V., and Van Leeuwen, C.: Grapevine responses to terroir: a global approach, J. Int. Sci. Vigne Vin, 39, 149-162, 2005.

Dion, R.: Le paysage et la vigne: essai de géographie historique, Payot, Paris, 1990 (in French).

Di Paola-Naranjo, R. D., Baroni, M. V., Podio, N. S., Rubinstein, H. R., Fabani, M. P., Badini, R. G., Inga, M., Ostera, H. A., Cagnoni, M., Gallegos, E., Gautier, E., Peral-García, P., Hoogewerff, J., and Wunderlin, D. A.: Fingerprints for main varieties of Argentinean wines: terroir differentiation by inorganic, organic, and stable isotopic analyses coupled to chemometrics, J. Agr. Food Chem., 59, 7854-7865, 2011.

Dobrowski, S. Z., Ustin, S. L., and Wolpert, J. A.: Grapevine dormant pruning weight prediction using remotely sensed data, Aust. J. Grape Wine R., 9, 177-182, 2003.

Dobrowski, S. Z., Ustin, S. L., and Wolpert, J. A.: Remote estimation of vine canopy density in vertically shoot-positioned vineyards: determining optimal vegetation indices, Aust. J. Grape Wine R., 8, 117-125, 2008.

Doolittle, J. A. and Brevik, E. C.: The use of electromagnetic induction techniques in soil studies, Geoderma, 223-225, 33-45, 2014.

Doré, T., Makowski, M., Malézieux, E., Munier-Jolain, N., Tchamitchian, M., and Tittonell, P.: Facing up to the paradigm of ecological intensification in agronomy: revisiting methods, concepts and knowledge, Eur. J. Agron., 34, 197-210, 2011.

El Azzi, D., Viers, J., Guiresse, M., Probst, A., Aubert, D., Caparros, J., Charles, F., Guizien, K., and Probst, J. L.: Origin and fate of copper in a small Mediterranean vineyard catchment, new insights from combined chemical extraction and $\delta^{65} \mathrm{Cu}$ isotopic composition, Sci. Total Environ., 463-464, 91-101, 2013. 
El Hadri, H., Chéry, P., Jalabert, S., Lee, A., Potin-Gautier, M., and Lespes, G.: Assessment of diffuse contamination of agricultural soil by copper in Aquitaine region by using French national databases, Sci. Total Environ., 441, 239-247, 2012.

Fernández-Calviño, D., Garrido-Rodríguez, B., López-Periago, J. E., Paradelo, M., and Arias-Estévez, M.: Spatial distribution of copper fractions in a vineyard soil, Land Degrad. Dev., 24, 556563, 2013.

Fiorillo, E., Crisci, A., De Filippis, T., Di Gennaro, S. F., Di Blasi, S., Matese, A., Primicerio, J., Vaccari, F. P., and Genesio, L.: Airborne high-resolution images for grape classification: changes in correlation between technological and late maturity in a Sangiovese vineyard in Central Italy, Aust. J. Grape Wine R., 18, 80-90, 2012.

Follain, S., Ciampalini, R., Crabit, A., Coulouma, G., and Garnier, F.: Effects of redistribution processes on rock fragment variability within a vineyard topsoil in Mediterranean France, Geomorphology, 175-176, 45-53, 2012.

Fulton, A., Schwankl, L., Lynn, K., Lampinen, B., Edstrom, J., and Prichard, T.: Using EM and VERIS technology to assess land suitability for orchard and vineyard development, Irrigation Sci., 29, 497-512, 2011.

Galleguillos, M., Jacob, F., Prévot, L., French, A., and Lagacherie, P.: Comparison of two temperature differencing methods to estimate daily evapotranspiration over a Mediterranean vineyard watershed from ASTER data, Remote Sens. Environ., 115, 13261340, 2011a.

Galleguillos, M., Jacob, F., Prévot, L., Lagacherie, P., and Liang, S.: Mapping daily evaporation over a Mediterranean vineyard watershed, IEEE Geosci. Remote S., 8, 168-172, $2011 \mathrm{~b}$.

Gilbert, J. A., Van der Lelie, D., and Zarraonaindia, I.: Microbial terroir for wine grapes, P. Natl Acad. Sci., 111, 5-6, 2014.

Gil-Pérez, B., Zarco-Tejada, P. J., Correa-Guimaraes, A., ReleaGangas, E., Navas-Gracia, L. M., Hernández-Navarro, S., SanzRequena, J. F., Berjón, A., and Martín-Gil, J.: Remote sensing detection of nutrient uptake in vineyards using narrow-band hyperspectral imagery, Vitis, 49, 167-173, 2010.

Girard, M. C.: Recherche d'une modélisation en vue d'une représentation spatiale de la couverture pédologique, Application à une région des plateaux jurassiques de Bourgogne, Thèse de doctorat d'Etat, Institut National Agronomique Paris-Grignon, Sols, 13, 1983 (in French).

Gong, P., Mahler, S. A., Biging, G. S., and Newburn, D. A.: Vineyard identification in a oak woodland landscape with airborne digital camera imagery, Int. J. Remote Sens., 24, 1303-1315, 2003.

Goulet, E., Dousset, S., Chaussod, R., Bartoli, F., Dolédec, A. F., and Andreux, F.: Water-stable aggregates and organic matter pools in a calcareous vineyard soil under four soil-surface management systems, Soil Use Manage., 20, 318-324, 2004.

Guilpart, N., Métay, A., and Gary, C.: Grapevine bud fertility and number of berries per bunch are determined by water and nitrogen stress around flowering in the previous year, Eur. J. Agron., 54, 9-20, 2014.

Hajkowitcz, S. and Young, M.: Costing yield loss from acidity, sodicity, and dryland salinity to Australian agriculture, Land Degrad. Dev., 16, 417-433, 2005.
Hall, A. and Jones, G. V.: Spatial analysis of climate in winegrape growing regions in Australia, Aust. J. Grape Wine R., 16, 389404, 2010.

Hall, A. and Wilson, M. A.: Object-based analysis of grapevine canopy relationships with winegrape composition and yield in two contrasting vineyards using multitemporal high spatial resolution optical remote sensing, Int. J. Remote Sens., 34, 17721797, 2013.

Hall, A., Lamb, D. W., Holzapfel, B. P., and Louis, J. P.: Optical remote sensing applications in viticulture - a review, Aust. J. Grape Wine R., 8, 36-47, 2002.

Hall, A., Louis, J., and Lamb, D.: Characterizing and mapping vineyard canopy using high-spatial-resolution aerial multispectral images, Comput. Geosci., 29, 813-822, 2003.

Hall, A., Louis, J. P., and Lamb, D. W.: Low-resolution remotely sensed images of winegrape vineyards map spatial variability in planimetric canopy instead of leaf area index, Aust. J. Grape Wine R., 14, 9-17, 2008.

Hall, A., Lamb, D. W., Holzapfel, B. P., and Louis, J. P.: Withinseason temporal variation in correlations between vineyard canopy and winegrape composition and yield, Precis. Agric., 12, 103-107, 2011.

Hanjra, M. A. and Qureshi, E.: Global water crisis and future food security in an era of climate change, Food Policy, 35, 365-377, 2010.

Haralick, R. M., Shanmugam, K., and Dinstein, I.: Textural features for image classification, IEEE T. Syst. Man. Cyb., 3, 610-621, 1973.

Hartemink, A. E. and Minasny, B.: Towards digital soil morphometrics, Geoderma, 230-231, 305-317, 2014.

Herrera-Nuñez, J. C., Ramazotti, S., Stagnari, F., and Pisante, M.: A multivariate clustering approach for characterization of the Montepulciano d'Abruzzo Colline Teramane area, Am. J. Enol. Vitic., 62, 239-244, 2011.

Herrero-Langreo, A., Tisseyre, B., Goutouly, J.P., Scholasch, T., and Van Leeuwen, C.: Mapping grapevine (Vitis vinifera L.) water status during the season using carbon isotope ratio $\left(\delta^{13} \mathrm{C}\right)$ as ancillary data, Am. J. Enol. Viticult., 64, 307-315, 2013.

Hijmans, R. J., Cameron, S. E., Parra, J. L., Jones, P. G., and Jarvis, A.: Very high resolution interpolated climate surfaces for global land areas, Int. J. Climatol., 25, 1965-1978, 2005.

Hole, F. D.: An approach to landscape analysis with emphasis on soil, Geoderma, 21, 1-23, 1978.

Hugues, P., McBratney, A. B., Malone, B. P., and Minasny, B.: Development of terrons for the Lower Hunter Valley wine-growing region, in: Digital soil assessments and beyond, edited by: Minasny, B., Malone, B. P., and McBratney, A. B., Taylor\&Francis, London, 31-36, 2012.

Iglesias, A., Garrote, L., Flores, F., and Moneo, M.: Challenges to manage the risk of water scarcity and climate change in the Mediterranean, Water Resour. Manage., 21, 775-788, 2007.

Jacobsen, R.: American Terroir: Savoring the Flavors of Our Woods, Waters, and Fields, Bloomsbury USA, New York, 2010.

Jacobson, A. R., Dousset, S., Guichard, N., Baveye, P. C., and Andreux, F.: Diuron mobility through vineyard soils contaminated with copper, Environ. Pollut., 138, 250-259, 2005.

Jacobson, A. R., Dousset, S., Andreux, F., and Baveye, P. C.: Electron microprobe and synchrotron X-ray fluorescence mapping of 
the heterogeneous distribution of copper in high-copper vineyard soils, Environ. Sci. Technol., 14, 6343-6349, 2007.

Johnson, L. F.: Temporal stability of an NDVI-LAI relationship in a Napa Valley vineyard, Aust. J. Grape Wine R., 9, 96-101, 2003.

Johnson, L. F., Roczen, D. E., Youkhana, S. K., Nemani, R. R., and Bosch, D. F.: Mapping vineyard leaf area with multispectral satellite imagery, Comput. Electron. Agr., 38, 33-44, 2003.

Jones, G. V. and Alves, F.: Spatial Analysis of Climate in Winegrape Growing Regions in Portugal, Proceedings of the 9th International Terroir Congress, 25-29 June, 2012, Burgundy and Champagne, France, Vol. 1, 1-4, 2012.

Jones, G. V. and Davis, R. E.: Climate influences on grapevine phenology, grape composition, and wine production and quality for Bordeaux, France, Am. J. Enol. Viticult., 51, 249-261, 2000.

Jones, G. V., Moriondo, M., Bois, B., Hall, A., and Duff, A.: Analysis of the spatial climate structure in viticulture regions worldwide, Bull. OIV, 944-946, 507-518, 2009.

Jones, G. V., Duff, A. A., Hall, A., and Myers, J. W.: Spatial analysis of climate in winegrape growing regions in the Western United States, Am. J. Enol. Viticult., 61, 313-326, 2010.

Komárek, M., Száková, J., Rohošková, M., Javorská, H., Chrastný, V., and Balík, J.: Copper contamination of vineyard soils from small wine producers: a case study from the Czech Republic, Geoderma, 147, 16-22, 2008.

Lacas, J. G., Carluer, N., and Voltz, M.: Efficiency of a grass buffer strip for limiting diuron losses from an uphill vineyard towards surface and subsurface waters, Pedosphere, 22, 580-592, 2012.

Lagacherie, P., Robbez-Masson, J. M., Nguyen-The, N., and Barthès, J. P.: Mapping of reference area representativity using a mathematical soilscape distance, Geoderma, 101, 105-118, 2001.

Lagacherie, P., Coulouma, G., Ariagno, P., Virat, P., Boizard, H., and Richard, G.: Spatial variability of soil compaction over a vineyard region in relation with soils and cultivation operations, Geoderma, 134, 207-216, 2006.

Lagacherie, P., Bailly, J. S., Monestiez, P., and Gomez, C.: Using scattered hyperspectral imagery data to map the soil properties of a region, Eur. J. Soil Sci., 63, 110-119, 2012.

Lai, H. Y., Juang, K. W., and Chen, B. C.: Copper concentrations in grapevines and vineyard soils in central Taiwan, Soil Sci. Plant Nutr., 56, 601-606, 2013.

Lamb, D. W., Weedon, M. M., and Bramley, R. G. V.: Using remote sensing to predict grape phenolics and colour at harvest in a Cabernet-Sauvignon vineyard: timing observations against vine phenology and optimising image resolution, Aust. J. Grape Wine R., 10, 46-54, 2004.

Lamb, D. W., Mitchell, A., and Hyde, G.: Vineyard trellising with steel posts distorts data from EM soil surveys, Aust. J. Grape Wine R., 11, 24-32, 2005.

Landry, D., Dousset, S., Fournier, J. C., and Andreux, F.: Leaching of glyphosate and AMPA under two soil management practices in Burgundy vineyards (Vosne-Romanée, 21-France), Environ. Pollut., 138, 191-200, 2005.

Lanjeri, S., Segarra, D., and Melia, J.: Interannual vineyard crop variability in the Castilla-La Mancha region during the period 1991-1996 with Landsat Thematic Mapper images, Int. J. Remote Sens., 25, 2441-2457, 2004.

Laville, P.: Le terroir, un concept indispensable à l'élaboration et à la protection des appellations d'origine comme à la gestion des vignobles: le cas de la France, Bull. OIV, 709-710, 217-241, 1990.

Le Bissonnais, Y., Blavet, D., De Noni, G., Laurent, J.-Y., Asseline, J., and Chenu, C.: Erodibility of Mediterranean vineyard soils: relevant aggregate stability methods and significant soil variables, Eur. J. Soil Sci., 58, 188-195, 2007.

Lebon, E., Dumas, V., Pieri, P., and Schultz, H. R.: Modelling the seasonal dynamics of the soil water balance of vineyards, Funct. Plant Biol., 30, 699-710, 2003.

Lee, J. and Steenwerth, K. L.: "Cabernet Sauvignon" grape anthocyanin increased by soil conservation practices, Scientia Hort 159, 128-133, 2013.

Lefrancq, M., Imfeld, G., Payraudeau, and Millet, M.: Kresoxim methyl deposition, drift and runoff in a vineyard catchment, Sci. Total Environ., 442, 503-508, 2013.

Lieskovsky, J. and Kenderessy, P.: Modelling the effect of vegetation cover and different tillage practices on soil erosion in vineyards: a case study in Vráble (Slovakia) using WATEM/SEDEM, Land Degrad. Dev., 25, 288-296, 2014.

Liguori, M., Tixier, M. S., Fabio Hernandes, A., Douin, M., and Kreiter, S.: Agroforestry management and phytoseiid communities in vineyards in the South of France, Exp. Appl. Acarol., 55, 167-181, 2011.

Llorens, J., Gil, E., Llop, J., and Queraltó, M: Georeferenced LiDAR 3D vine plantation map generation, Sensors, 11, 62376256, doi:10.3390/s110606237, 2011.

López-Rituerto, E., Savorani, F., Avenoza, A., Busto, J. H., Peregrina, J. M., and Balling Engelsen, S.: Investigations of la Rioja terroir for wine production using ${ }^{1} \mathrm{H}$ NMR metabolomics, J. Agr. Food Chem., 60, 3452-3461, 2012.

Louchart, X. and Voltz, M.: Aging effects on the availability of herbicides to runoff transfer, Environ. Sci. Technol., 41, 1137-1144, 2007.

Luvisi, A., Pagano, M., Bandinelli, R., Rinaldelli, E., Gini, B., Scartòn, M., Manzoni, G., and Triolo, E.: Virtual vineyard for grapevine management purposes: A RFID/GPS application, Comput. Electron. Agr., 75, 368-371, 2011.

Mackie, K. A., Müller, T., Zikeli, S., and Kandeler, E.: Long-term copper application in an organic vineyard modifies spatial distribution of micro-organisms, Soil Biol. Biochem., 65, 245-253, 2013.

Malone, B. P., Hugues, P., McBratney, A. B., and Minasny, B.: A model for the identification of terrons in the Lower Hunter Valley, Australia, Geoderma Reg., 1, 31-47, 2014.

Manandhar, R., Odeh, I. O. A., and Pontius Jr., R. G.: Analysis of twenty years of categorical land transitions in the Lower Hunter of New South Wales, Australia, Agr. Ecosyst. Environ., 135, 336-346, 2010.

Marchionni, S., Braschi, E., Tommasini, S., Bollati, A., Cifelli, F., Mulinacci, N., Mattei, M., and Conticelli, S.: High precision ${ }^{87} \mathrm{Sr} /{ }^{86} \mathrm{Sr}$ analyses in wines and their use as geological fingerprint for tracing geographic provenance, J. Agr. Food Chem., 61, 6822-6831, 2013.

Marre, A.: Existe-t-il des terroirs en Champagne?, Revue Géographique de l'Est, 1-2, 17-30, 2004 (in French).

Martín, P., Zarco-Tejada, P. J., González, M. R., and Berjón, A.: Using hyperspectral remote sensing to map grape quality in "Tempranillo" vineyards affected by iron deficiency chlorosis, Vitis, 46, 7-14, 2007. 
Martínez-Casasnovas, J. A., Ramos, M. C., and García-Hernández, D.: Effects of land-use changes in vegetation cover and sidewall erosion in a gully head of the Penedès region (northeast Spain), Earth Surf. Proc. Land., 34, 1927-1937, 2009.

Martínez-Casasnovas, J. A., Agelet-Fernandez, J., Arnó, J., and Ramos, M. C.: Analysis of vineyard differential management zones and relation to vine development, grape maturity and quality, Spanish J. Agr. Res., 10, 326-337, 2012.

Martínez-Casasnovas, J. A., Ramos, M. C., and Benites, G.: Soil and water assessment tool soil loss simulation at the sub-basin scale in the Alt Penedès-Anoia vineyard region (NE Spain) in the 2000s, Land Degrad. Dev., online first, doi:10.1002/ldr.2240, 2013.

Martini, E., Comina, C., Priori, S., and Costantini, E. A. C.: A combined geophysical-pedological approach for precision viticulture in the Chianti hills, Bollettino di Geofisica Teorica ed Applicata, 54, 165-181, 2013.

Martins, G., Lauga, B., Miot-Sertier, C., Mercier, A., Lonvaud, A., Soulas, M. L., Soulas, G., and Masneuf-Pomarède, I.: Characterization of epiphytic bacterial communities from grapes, leaves, bark and soil of grapevine plants grown, and their relations, Plos one, 8, e73013, 1-9, 2013.

Matheron, G.: Traité de géostatistique appliquée, Tome 1, Editions Technip, Paris, France, 1962 (in French).

Matheron, G.: Les variables régionalisées et leur estimation: une application de la théorie des fonctions aléatoires aux sciences de la nature, Masson, Paris, 1965 (in French).

Mathews, A. J. and Jensen, J. L. R.: An airborne LiDAR-based methodology for vineyard parcel detection and delineation, Int. J. Remote Sens., 33, 5251-5267, 2012.

Mathews, A. J. and Jensen, J. L. R.: Visualizing and quantifying vineyard canopy LAI using an Unmanned Aerial Vehicle (UAV) collected high density structure from motion point cloud, Remote Sens., 5, 2164-2183, 2013.

Mazzetto, F., Calcante, A., Mena, A., and Vercesi, A.: Integration of optical and analogue sensors for monitoring canopy health and vigour in precision viticulture, Precis. Agric., 11, 636-649, 2010.

Meggio, F., Zarco-Tejada, P. J., Núñez, L. C., Sepulcre-Cantó, G., González, M. R., and Martín, P.: Grape quality assessment in vineyards affected by iron deficiency chlorosis using narrowband physiological remote sensing indices, Remote Sens. Environ., 114, 1968-1986, 2010.

Mercurio, M., Grilli, E., Odierna, P., Morra, V., Prohaska, T., Coppola, E., Grifa, C., Buondonno, A., and Langella, A.: A "GeoPedo-Fingerprint" (GPF) as a tracer to detect univocal parent material-to-wine production chain in high quality vineyard districts, Campi Flegrei (Southern Italy), Geoderma, 230-231, 6478, 2014.

Minasny, B., Whelan, B. M., Triantafilis, J., and McBratney, A. B.: Pedometrics research in the vadose zone-review and perspectives, Vadose Zone J., Special section: Digital soil mapping, 12, 4, doi:10.2136/vzj2012.0141, 2013.

Mirlean, N., Roisenberg, A., and Chies, J. O.: Metal contamination of vineyard soils in wet subtropics (Southern Brazil), Bull. Environ. Contam. Toxicol., 82, 373-377, 2007.

Mirlean, N., Baisch, P., and Medeanic, S.: Copper bioavailability and fractionation in copper-contaminated sandy soils in the wet subtropics (Southern Brazil), Bull. Environ. Contam. Toxicol., 82, 373-377, 2009.
Mocali, S. and Benedetti, A.: Exploring research frontiers in microbiology: the challenge of metagenomics in soil microbiology, Res. Microbiol., 161, 497-505, 2010.

Mocali, S., Fabiani, A., Kuramae, E., de Hollander, M., Kowalchuk, G. A., Vignozzi, N., Valboa, G., and Costantini, E.: Genetic and functional diversity of soil microbial communities associated to grapevine plants and wine quality, Geophys. Res. Abstr., EGU2013-1187-1, EGU General Assembly 2013, Vienna, Austria, 2013.

Montes, C., Lhomme, J. P., Demarty, J., Prévot, L., and Jacob, F.: A three-source SVAT modeling of evaporation: application to the seasonal dynamics of a grassed vineyard, Agr. Forest Meteorol., 191, 64-80, 2014.

Morari, F., Castrignanò, A., and Pagliarin, C.: Application of multivariate geostatistics in delineating management zones within a gravelly vineyard using geo-electrical sensors, Comput. Electron. Agr., 68, 97-107, 2009.

Myrold, D. D. and Nannipieri, P.: Classical techniques versus omics approaches, in: Omics in soil Science, edited by: Nannipieri, P., Pietramellara, G., and Renella, G., Caster Academic Press, Norfolk, UK, 179-187, 2014.

Nannipieri, P., Ascher, J., Ceccherini, M., Landi, L., Pietramellara, G., and Renella, G.: Microbial diversity and soil functions, Eur. J. Soil Sci., 54, 655-670, 2003.

Nendel, C. and Kersebaum, K. C.: A simple model approach to simulate nitrogen dynamics in vineyard soils, Ecol. Model., 177, 115, 2004.

Novara, A., Gristina, L., Saladino, S. S., Santoro, A., and Cerdà, A.: Soil erosion assessment on tillage and alternative soil managements in a Sicilian vineyard, Soil Till. Res., 117, 140-147, 2011.

Novara, A., Gristina, L., Guaitoli, F., Santoro, A., and Cerdà, A.: Managing soil nitrate with cover crops and buffer strips in Sicilian vineyards, Solid Earth, 4, 255-262, 2013.

Oliver, M. A. and Webster, R.: A tutorial guide to geostatistics: computing and modelling variograms and kriging, Catena, 113, 5669, 2014.

Paranychianakis, N. V. and Angelakis, A. N.: The effect of water stress and rootstock on the development of leaf injuries in grapevines irrigated with saline effluent, Agr. Water Manage., 95, 375-382, 2008.

Paroissien, J. B., Lagacherie, P., and Le Bissonnais, Y.: A regionalscale study of multi-decennial erosion of vineyard fields using vine-stock unearthing-burying measurements, Catena, 82, 159168, 2010.

Pedroso, M., Taylor, J., Tisseyre, B., Charnomordic, B., and Guillaume, S.: A segmentation algorithm for the delineation of agricultural management zones, Comput. Electron. Agr., 70, 199208, 2010.

Pereira, G. E., Gaudillère, J. P., Van Leeuwen, C., Hilbert, G., Maucourt, M., Deborde, C., Moing, A., and Rolin, D.: ${ }^{1 \mathrm{H}}$ NMR metabolite fingerprints of grape berry: comparison of vintage and soil effects in Bordeaux grapevine growing areas, Anal. Chim. Acta, 563, 346-352, 2006.

Pietrzak, U. and McPhail, D. C.: Copper accumulation, distribution and fractionation in vineyard soils of Victoria, Australia, Geoderma, 122, 151-166, 2004. 
Pinto, C., Pinho, D., Sousa, S., Pinheiro, M., Egas, C., and Gomes, A. C.: Unraveling the diversity of the grapevine microbiome, Plos One, 9, e85622, doi:10.1371/journal.pone.0085622, 2014.

Plan Bleu: Mediterranean strategy for sustainable development follow-up, Main indicators, 2013 update, available at: http:// planbleu.org/sites/default/files/publications/idd_2013en.pdf (last access: 13 March 2015), 2013.

Primicerio, J., Di Gennaro, S. F., Fiorillo, E., Genesio, L., Lugato, E., Matese, A., and Vaccari, F. P.: A flexible unmanned aerial vehicle for precision agriculture, Precis. Agric., 13, 517-523, 2012.

Priori, S., Fantappiè, M., Magini, S., and Costantini, E. A. C.: Using the ARP-03 for high-resolution mapping of calcic horizons, Int. Agrophys., 27, 313-321, 2013a.

Priori, S., Martini, E., Andrenelli, M. C., Magini, S., Agnelli, A. E., Bucelli, P., Biagi, M., Pellegrini, S., and Costantini, E. A. C.: Improving wine quality through harvest zoning and combined use of remote and proximal sensing, Soil Sci. Soc. Am. J., 77, 1338-1348, 2013b.

Priori, S., Barbetti, R., L'Abate, G., Bucelli, P., Storchi, P., and Costantini, E. A. C.: Natural terroir units, Siena province, Tuscany, Journal Maps, 10, 466-477, 2014.

Puletti, N., Perria, R., and Storchi, P.: Unsupervised classification of very high remotely sensed images for grapevine rows detection, Eur. J. Remote Sens., 47, 45-54, 2014.

Quénol, H. and Bonnardot, V.: A multi-scale climatic analysis of viticultural terroirs in the context of climate change: the TERADCLIM Project, J. Int. Sci. Vigne Vin, Special Issue Laccave, 25-34, 2014.

Quiquerez, A., Chevigny, E., Allemand, P., Curmi, P., Petit, C., and Grandjean, P.: Assessing the impact of soil surface characteristics on vineyard erosion from very high spatial resolution aerial images (Côte de Beaune, Burgundy, France), Catena, 116, 163$172,2014$.

Rabatel, G., Debain, C., Delenne, C., and Deshayes, M.: "Bacchus" methodological approach for vineyard inventory and management, edited by: Montesinos Aranda, S. and Quintanilla, A., European Commission, DG Research, RTD action: energy, environment and sustainable development, 67-87, 2006.

Rabatel, G., Delenne, C., and Deshayes, M.: A non-supervised approach using Gabor filters for vine-plot detection in aerial images, Comput. Electron. Agr., 62, 159-168, 2008.

Ramos, M. C. and Martínez-Casasnovas, J. A.: Nutrient losses by runoff in vineyards of the Mediterranean Alt Penedès region (NE Spain), Agr. Ecosyst. Environ., 113, 356-363, 2006.

Ramos, M. C. and Martínez-Casasnovas, J. A.: Soil water variability and its influence on transpirable soil water fraction with two grape varieties under different rainfall regimes, Agr. Ecosyst. Environ., 185, 253-262, 2014.

Renouf, V., Claisse, O., and Lonvaud-Funel, A.: Understanding the microbial ecosystem on the grape berry surface through numeration and identification of yeast and bacteria, Aust. J. Grape Wine R., 11, 316-327, 2005.

Renouf, V., Claisse, O., and Lonvaud-Funel, A.: Inventory and monitoring of wine microbial consortia, Appl. Microbiol. Biotechnol., 75, 149-164, 2007.

Riches, D., Porter, I. J., Oliver, D. P., Bramley, R. G. V., Rawnsley, B., Edwards, J., and White, R. E.: Review: soil biological properties as indicators of soil quality in Australian viticulture, Aust. J. Grape Wine R., 19, 311-323, 2013.
Riou, C., Valancogne, C., and Pieri, P.: Un modèle simple d'interception du rayonnement solaire par la vigne. Vérification expérimentale, Agronomie, 9, 441-450, 1989 (in French).

Riou, C., Pieri, P., and Le Clech, B.: Consommation d'eau de la vigne en conditions hydriques non limitantes, Formulation simplifies de la transpiration, Vitis, 33, 109-115, 1994 (in French).

Ripoche, A., Celette, F., Cinna, J. P., and Gary, C.: Design of intercrop management plans to fulfil production and environmental objectives in vineyards, Eur. J. Agron., 32, 30-39, 2010.

Ripoche, A., Metay, A., Celette, F., and Gary, C.: Changing the soil surface management in vineyards: immediate and delayed effects on the growth and yield of grapevine, Plant. Soil, 339, 259-271, 2011.

Rodríguez-Pérez, J. R., Riaño, D., Carlisle, E., Ustin, S., and Smart, D. R.: Evaluation of hyperspectral reflectance indexes to detect grapevine water status in vineyards, Am. J. Enol. Viticult., 58, 302-317, 2007.

Rodríguez-Pérez, J. R., Álvarez-López, C. J., Miranda, D., and Álvarez, M. F.: Vineyard area estimation using medium spatial resolution satellite imagery, Span. J. Agric. Res., 6, 441-452, 2008.

Rodríguez-Pérez, J. R., Plant, R. E., Lambert, J. J., and Smart, D. R.: Using apparent soil electrical conductivity (ECa) to characterize vineyard soils of high clay content, Precis. Agric., 12, 775-794, 2011.

Rossi, R., Pollice, A., Diago, M. P., Oliveira, M., Millan, B., Bitella, G., Amato, M., and Tardaguila, J.: Using an automatic resistivity profiler soil sensor on-the-go in precision viticulture, Sensors, 13, 1121-1136, 2013.

Roudier, P., Tisseyre, B., Poilvé, H., and Roger, J. M.: Management zone delineation using a modified watershed algorithm, Precis. Agric., 9, 233-250, 2008.

Roudier, P., Tisseyre, B., Poilvé, H., and Roger, J. M.: A technical opportunity index adapted to zone-specific management, Precis. Agric., 12, 130-145, 2011.

Ruiz-Colmenero, M., Bienes, R., and Marques, M. J.: Soil and water conservation dilemmas associated with the use of green cover in steep vineyards, Soil Till. Res., 117, 211-223, 2011.

Ruiz-Colmenero, M., Bienes, R., Eldridge, D. J., and Marques, M. J.: Vegetation cover reduces erosion and enhances soil organic carbon in a vineyard in the central Spain, Catena, 104, 153-160, 2013.

Rusjan, D., Strlič, M., Pucko, D., and Korošec-Koruza, Z.: Copper accumulation regarding the soil characteristics in subMediterranean vineyards of Slovenia, Geoderma, 141, 111-118, 2007.

Salome, C., Coll, P., Lardo, E., Villenave, C., Blanchart, E., Hinsinger, P., Marsden, C., and Le Cadre, E.: Relevance of use-invariant soil properties to assess soil quality of vulnerable ecosystems: The case of Mediterranean vineyards, Ecol. Indic., 43, 83-93, 2014.

Samouëlian, A., Cousin, I., Tabbagh, A., Bruand, A., and Richard, G.: Electrical resistivity survey in soil science: a review, Soil Till. Res., 83, 173-193, 2005.

Santesteban, L. G., Guillaume, S., Royo, J. B., and Tisseyre, B.: Are precision agriculture tools and methods relevant at the wholevineyard scale?, Precis. Agric., 14, 2-17, 2013.

Schmidt, H. P., Kammann, C., Niggli, C., Evangelou, M. W. H., Mackie, K. A., and Abiven, S.: Biochar and biochar-compost as soil amendments to a vineyard soil: influences on plant growth, 
nutrient uptake, plant health and grape quality, Agr. Ecosyst. Environ., 191, 117-123, 2014.

Scholander, P. F., Bradstreet, E. D., Hemmingsen, E. A., and Hammel, H. T.: Sap pressure in vascular plants. Negative hydrostatic pressure can be measured in plants, Science, 148, 3668, 339-346, 1965.

Setati, M. E., Jacobson, D., Andong, U. C., and Bauer, F.: The vineyard yeast microbiome, a mixed model microbial map, Plos One, 7, e52609, doi:10.1371/journal.pone.0052609, 2012.

Son, H. S., Hwang, G. S., Kim, K. M., Ahn, H. J., Park, W. M., Van Den Berg, F., Hong, Y. S., and Lee, C. H.: Metabolomic studies on geographical grapes and their wines using ${ }^{1} \mathrm{H}$ NMR analysis coupled with multivariate statistics, J. Agr. Food Chem., 57, 1481-1490, 2009.

Stamatiadis, S., Taskos, D., Tsadila, E., Christofides, C., Tsadilas, C., and Schepers, J. S.: Comparison of passive and active canopy sensors for the estimation of vine biomass production, Precis. Agric., 11, 306-315, 2010.

Steenwerth, K. and Belina, K. M.: Cover crops enhance soil organic matter, carbon dynamics and microbiological function in a vineyard agroecosystem, Appl. Soil Ecol., 40, 359-369, 2008.

Steenwerth, K. L. and Belina, K. M.: Vineyard weed management practices influence nitrate leaching and nitrous oxide emissions, Agr. Ecosyst. Environ., 138, 127-131, 2010.

Steenwerth, K. L., Pierce, D. L., Carlisle, E. A., Spencer, R. G. M., and Smart, D. R.: A vineyard agroecosystem. Disturbance and precipitation affect soil respiration under Mediterranean conditions, Soil Sci. Soc. Am. J., 74, 231-239, 2010.

Stevens, R. M., Pech, J. M., Gibberd, M. R., Walker, R. R., and Nicholas, P. R.: Reduced irrigation and rootstock effects on vegetative growth, yield and its components, and leaf physiological responses of Shiraz, Aust. J. Grape Wine R., 16, 413-425, 2010.

Stevens, R. M., Harvey, G., Norton, S., and Frahn, W.: Over-canopy saline sprinkler irrigation of grapevines during different growth stages, Agr. Water Manage., 101, 62-70, 2011.

Tagarakis, A., Liakos, V., Fountas, S., Koundouras, S., and Gemtos, T. A.: Management zones delineation using fuzzy clustering techniques in grapevines, Precis. Agric., 140, 18-39, 2013.

Tan, Z. X., Lal, R., and Wiebe, K. D.: Global soil nutrient depletion and yield reduction, J. Sustain. Agr., 26, 123-146, 2005.

Tarolli, P., Sofia, G., Calligaro, S., Prosdocimi, M., Preti, F., and Dalla Fontana, G.: Vineyards in terraced landscapes: new opportunities from Lidar data, Land Degrad. Dev., 26, 92-102, 2015.

Tarr, P. T., Dreyer, M. L., Athanas, M., Shahgholi, M., Saarloos, K., and Second, T. P.: A metabolomics based approach for understanding the influence of terroir in Vitis Vinifera L., Metabolomics, 9, S170-S177, 2013.

Tatti, E., Goyer, C., Zebarth, B. J., Burton, D. L., Giovanetti, L., and Viti, C.: Short-term effects of mineral and organic fertilizer on denitrifiers, nitrous oxide emissions and denitrification in longterm amended vineyard soils, Soil Sci. Soc. Am. J., 77, 113-122, 2012.

Taylor, J. A., McBratney, A. B., and Whelan, B. M.: Establishing management classes for broadacre agricultural production, Agron. J., 99, 1366-1376, 2007.

Taylor, J. A., Coulouma, G., Lagacherie, P., and Tisseyre, B.: Mapping soil units within a vineyard using statistics associated with high-resolution apparent soil electrical conductivity data and factorial discriminant analysis, Geoderma, 153, 278-284, 2009.
Taylor, J. A., Acevedo-Opazo, C., Ojeda, H., and Tisseyre, B.: Identification and significance of sources of spatial variation in grapevine water status, Aust. J. Grape Wine R., 16, 218-226, 2010.

Taylor, J. A., Jacob, F., Galleguillos, M., Prévot, L., Guix, N., and Lagacherie, P.: The utility of remotely-sensed vegetative and terrain covariates at different spatial resolutions in modelling soil and watertable depth (for digital soil mapping), Geoderma, 193194, 83-93, 2013.

Tempesta, T., Giancristofaro, R. A., Corain, L., Salmaso, L., Tomasi, D., and Boatto, V.: The importance of landscape in wine quality perception: An integrated approach using choice-based conjoint analysis and combination-based permutation tests, Food Qual. Prefer., 21, 827-836, 2010.

Thornton, P. E., Running, S. W., and White, M. A.: Generating surfaces of daily meteorology variables over large regions of complex terrain, J. Hydrol., 190, 214-251, 1997.

Tisseyre, B. and McBratney, A. B.: A technical opportunity index based on mathematical morphology for site-specific management: an application to viticulture, Precis. Agric., 9, 101-103, 2008.

Tisseyre, B., Mazzoni, C., and Fonta, H.: Within-field temporal stability of some parameters in viticulture: potential toward a site specific management, J. Int. Sci. Vigne Vin, 42, 27-39, 2008.

Tomasi, D., Gaiotti, F., and Jones, G. V.: The power of the terroir: the case study of Prosecco wine, Springer, Basel, 2013.

Trought, M. C. T. and Bramley, R. G. V.: Vineyard variability in Malborough, New Zealand: characterizing spatial and temporal changes in fruit composition and juice quality in the vineyard, Aust. J. Grape Wine R., 17, 79-89, 2011.

Trubek, A. B.: Taste of Place: A Cultural Journey into Terroir, University of California Press, Berkeley and Los Angeles, California, 2008.

Tucker, C. J.: Red and photographic infrared linear combinations for monitoring vegetation, Remote Sens. Environ., 8, 127-150, 1979.

Unamunzaga, O., Besga, G., Castellón, A., Usón, M. A., Chéry, P., Gallejones, P., and Aizpurua, A.: Spatial and vertical analysis of soil properties in a Mediterranean vineyard soil, Soil Use Manage., 30, 285-296, doi:10.1111/sum.12110, 2014.

Unwin, T.: Vine and the wine: an historical geography of viticulture and the wine trade, Routledge, London, 1991.

Urdanoz, V. and Araguiés, R.: Three-year field response of dripirrigated grapevine (Vitis vinifera L., cv. Tempranillo) to soil salinity, Plant Soil, 324, 219-230, 2009.

Urretavizcaya, I., Santesteban, L. G., Tisseyre, B., Guillaume, S., Miranda, C., and Royo, J. B.: Oenological significance of vineyard management zones delineated using early grape sampling, Precis. Agric., 9, 101-103, 2013.

Van Leeuwen, C. and Seguin, G.: The concept of terroir in viticulture, J. Wine Res., 17, 1-10, 2006.

Van Leeuwen, C., Friant, P., Choné, X., Tregoat, O., Koundouras, S., and Dubourdieu, D.: The influence of climate, soil and cultivar on terroir, Am. J. Enol. Viticult., 55, 207-217, 2004.

Vaudour, E.: The quality of grapes and wine in relation to geography: notions of terroir at various scales, J. Wine Res., 13, 117 $141,2002$.

Vaudour E.: Les terroirs viticoles, Dunod, Paris, 2003 (in French). 
Vaudour, E.: Remote sensing of Red Mediterranean soils: a case study in the viticultural Southern Rhone Valley (France) using SPOT satellite imagery, Geocarto Int., 23, 197-216, 2008.

Vaudour, E. and Boulay, T.: Towards a spatial analysis of ancient viticultural areas: the case study of Amos (Turkey), Food History, 11, 157-176, 2013.

Vaudour, E., Girard, M. C., Brémond, L. M., and Lurton, L.: Caractérisation spatiale et constitution des raisins en AOC Côtes-duRhône méridionales (Bassin de Nyons-Valréas), J. Int. Sci. Vigne Vin, 32, 169-182, 1998.

Vaudour, E., Carey, V. A., and Gilliot, J. M.: Digital zoning of South African viticultural terroirs using bootstrapped decision trees on morphometric data and multitemporal SPOT images, Remote Sens. Environ., 114, 2940-2950, 2010.

Vaudour, E., Carey, V. A., and Gilliot, J. M.: Multidate remote sensing approaches for digital zoning of terroirs at regional scales: case studies revisited and perspectives, Geophys. Res. Abstr., EGU2014-11533, EGU General Assembly 2014, Vienna, Austria, 2014a.

Vaudour, E., Gilliot, J. M., Bel, L., Bréchet, L., Hadjar, D., Hamiache, J., and Lemonnier, Y.: Uncertainty of soil reflectance retrieval from SPOT and RapidEye multispectral satellite images using a per-pixel bootstrapped empirical line atmospheric correction over an agricultural region, Int. J. Appl. Earth Obs., 26, 217-234, 2014b.

Vega-Avila, A. D., Gumiere, T., Andrade, P. A. M., Lima-Perim, J. E., Durrer, A., Baigori, M., Vazquez, F., and Andreote, F. D.: Bacterial communities in the rhizosphere of Vitis vinifera L. cultivated under distinct agricultural practices in Argentina, Antonie van Leeuwenhoek, 107, 575-588, doi:10.1007/s10482014-0353-7, 2015.

Verger, A., Vigneau, N., Chéron, C., Gilliot, J. M., Comar, A., and Baret, F.: Green area index from an unmanned aerial system over wheat and rapeseed crops, Remote Sens. Environ., 152, 654-664, 2014.

Vincent, L. and Soille, P.: Watershed in digital spaces - An efficient algorithm based on immersion simulations, IEEE T. Pattern Anal., 13, 583-598, 1991.

Vogel, T. M., Simonet, P., Jansson, J. K., Hirsch, P. R., Tiedje, J. M., Van Elsas, J. D., Bailey, M. J., Nalin, R., and Philippot, L.: TerraGenome: a consortium for the sequencing of a soil metagenome, Nat. Rev. Microbiol., 7, 252, doi:10.1038/nrmicro2119, 2009.

Walker, R. R., Blackmore, D. H., Clingeleffer, D. R., and Correll, R. L.: Rootstock effects on salt tolerance of irrigated field-grown grapevines (Vitis vinifera L. cv. Sultana). 1. Yield and vigour inter-relationships, Aust. J. Grape Wine R., 8, 3-14, 2002.
Warner, T. A. and Steinmaus, K.: Spatial classification of orchards and vineyards with high spatial resolution panchromatic imagery, Photogramm. Eng. Rem. S., 71, 179-187, 2005.

Wassenaar, T., Robbez-Masson, J. M., Andrieux, P., and Baret, F.: Vineyard identification and description of spatial crop structure by per-field frequency analysis, Int. J. Remote Sens., 23, 33113325, 2002.

Wassenaar, T., Andrieux, P., Baret, F., and Robbez-Masson, J. M.: Soil surface infiltration capacity classification based on the bidirectional reflectance distribution function sampled by aerial photographs. The case of vineyards in a Mediterranean area, Catena, 62, 94-110, 2005.

Werban, U., Bartholomeus, H., Dietrich, P., Grandjean, G., and Zacharias, S.: Digital soil mapping: approaches to integrate sensing techniques to the prediction of key soil properties, Vadose Zone J., Special section: Digital soil mapping, 12, 1-4, doi:10.2136/vzj2013.10.0178, 2013.

Wezel, A., Casagrande, M., Celette, F., Vian, J. F., Ferrer, A., and Peigné, J.: Agroecological practices for sustainable agriculture. A review, Agron. Sustain. Dev., 34, 1-20, 2014.

Wightwick, A. M., Mollah, M. R., Partington, D. L., and Allinson, G.: Copper fungicide residues in Australian vineyard soils, J. Agr. Food Chem., 56, 2457-2464, 2008.

White, R., Balachandra, L., Edis, R., and Chen, D.: The soil component of terroir, J. Int. Sci. Vigne Vin, 41, 9-18, 2007.

Zarco-Tejada, P. J., Berjón, A., López-Lozano, R., Miller, J. R., Martín, P., Cachorro, V., González, M. R., and de Frutos, A.: Assessing vineyard condition with hyperspectral indices: leaf and canopy reflectance simulation on, a row-structured discontinuous canopy, Remote Sens. Environ., 99, 271-287, 2005.

Zarco-Tejada, P. J., Guillén-Climent, M. L., Hernández-Clemente, R., Catalina, A., González, M. R., and Martín, P.: Estimating leaf carotenoid content in vineyards using high resolution hyperspectral imagery acquired from an unmanned aerial vehicle (UAV), Agr. Forest. Meteorol., 171-172, 281-294, 2013.

Zornoza, R., Acosta, J. A., Bastida, F., Domínguez, S. G., Toledo, D. M., and Faz, A.: Identification of sensitive indicators to assess the interrelationship between soil quality, management practices and human health, SOIL, 1, 173-185, doi:10.5194/soil-1-173-2015, 2015. 